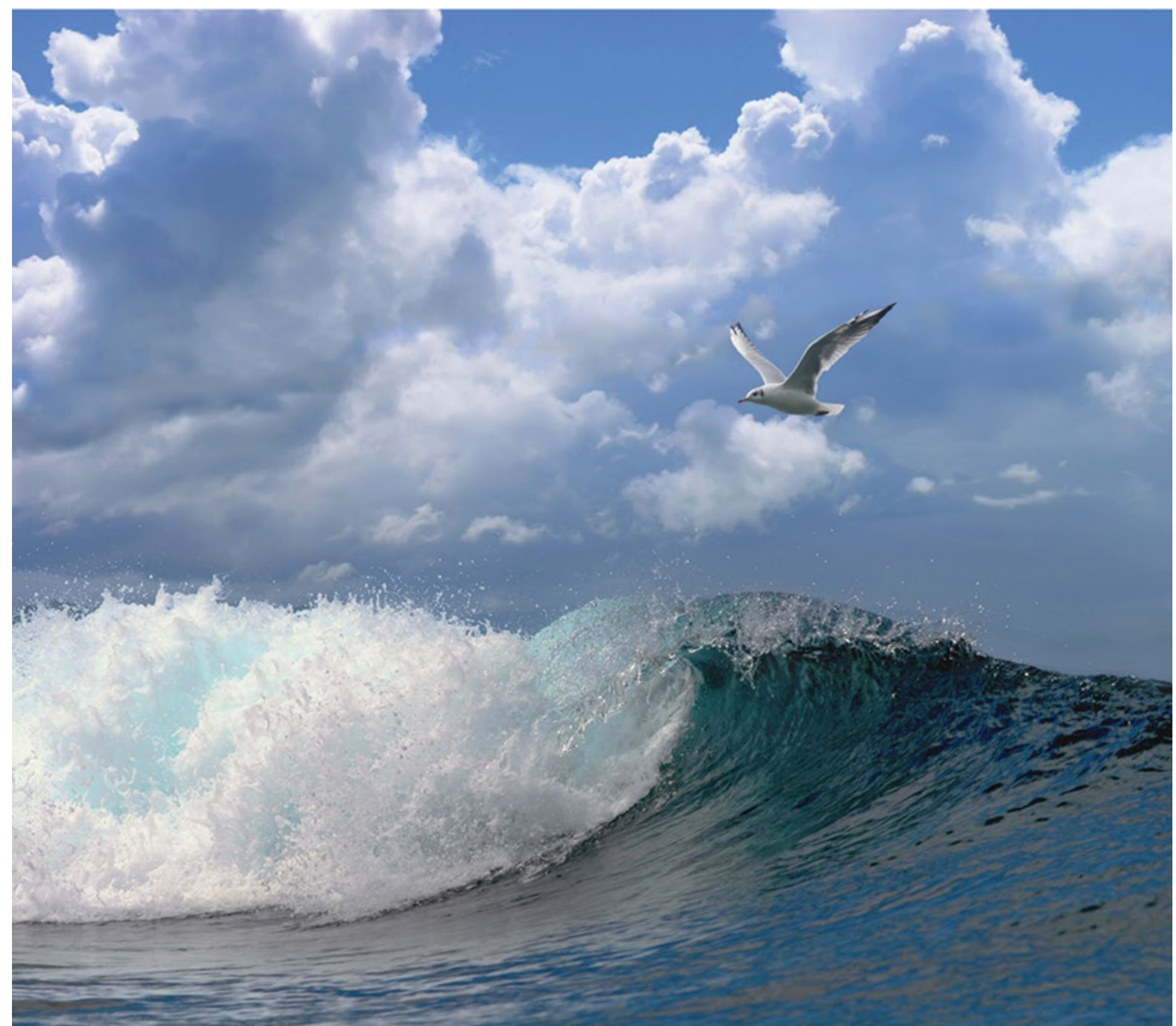

\title{
Metingen aan kokkelsterfte in de Oosterschelde in de zomer van 2019 en 2020
}




\section{Metingen aan kokkelsterfte in de Oosterschelde in de zomer van 2019 en 2020}

Auteurs: Lisanne van den Bogaart, Margriet van Asch, Wouter Suykerbuyk en Karin Troost

Wageningen Marine Research 
Keywords: kokkelsterfte, temperatuur, Oosterschelde, intergetijdengebied

Opdrachtgever: Ministerie van Landbouw, Natuur en Voedselkwaliteit

T.a.v.: Wilbert Schermer Voest

Bezoudenhoutseweg 73

2594 AC Den Haag

KB-36-002-012

Dit rapport is gratis te downloaden van https://doi.org/10.18174/544576

Wageningen Marine Research verstrekt geen gedrukte exemplaren van rapporten.

Wageningen Marine Research is ISO 9001:2015 gecertificeerd.

(C) Wageningen Marine Research

Wageningen Marine Research, instituut binnen de rechtspersoon Stichting

Wageningen Research, hierbij

vertegenwoordigd door Dr. M.C.Th.

Scholten, Algemeen directeur

KvK nr. 09098104,

WMR BTW nr. NL 8113.83.696.B16.

Code BIC/SWIFT address: RABONL2U

IBAN code: NL 73 RABO 0373599285
Wageningen Marine Research aanvaardt geen aansprakelijkheid voor gevolgschade, noch voor schade welke voortvloeit uit toepassingen van de resultaten van werkzaamheden of andere gegevens verkregen van Wageningen Marine Research. Opdrachtgever vrijwaart Wageningen Marine Research van aanspraken van derden in verband met deze toepassing.

Alle rechten voorbehouden. Niets uit deze uitgave mag weergegeven en/of gepubliceerd worden, gefotokopieerd of op enige andere manier gebruikt worden zonder schriftelijke toestemming van de uitgever of auteur. 


\section{Inhoud}

$\begin{array}{lr}\text { Samenvatting } & 4\end{array}$

$1 \quad$ Inleiding $\quad 5$

1.1 Achtergrond $\quad 5$

1.2 Probleemstelling $\quad 5$

$\begin{array}{lll}1.3 & \text { Doelstelling } & 5\end{array}$

$\begin{array}{lll}1.4 & \text { Leeswijzer } & 6\end{array}$

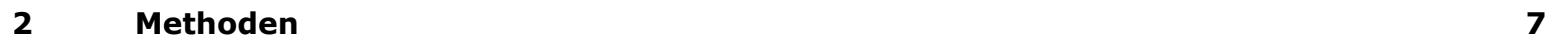

$\begin{array}{lll}2.1 & \text { Locaties } & 7\end{array}$

$\begin{array}{lll}2.1 .1 & 2019 & 7\end{array}$

$\begin{array}{llll}2.1 .2 & 2020 & 9\end{array}$

2.2 Monstername $\quad 9$

\begin{tabular}{ll}
2.3 & Labverwerking \\
\hline
\end{tabular}

$\begin{array}{ll}2.4 & \text { Sterfteanalyse } \\ \end{array}$

$\begin{array}{llr}3 & \text { Resultaten } & 11\end{array}$

3.1 Sterfte in $2019 \quad 11$

3.2 Sterfte in $2020 \quad 12$

$\begin{array}{llr}4 & \text { Literatuur review } & 15\end{array}$

$4.1 \quad$ Optimale temperatuurrange 15

4.2 Directe effecten van hoge temperaturen 16

4.3 Indirecte effecten van hoge temperaturen 16

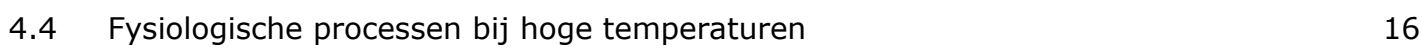

$\begin{array}{lll}4.5 & \text { Zomersterfte in het buitenland } & 17\end{array}$

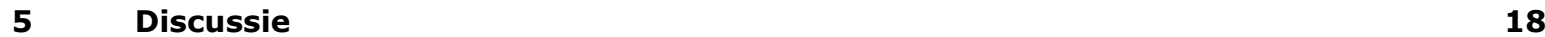

$\begin{array}{llr}5.1 & \text { Sterfte } & 18\end{array}$

$\begin{array}{ll}5.2 & \text { Koppeling hittestress } \\ 5.3 & 19\end{array}$

$\begin{array}{ll}5.3 \text { Methodiek } & 22\end{array}$

$\begin{array}{lll}5.4 & \text { Toekomst } & 22\end{array}$

$\begin{array}{lll}5.5 & \text { Aanbevelingen } & 23\end{array}$

$\begin{array}{llr}6 & \text { Kwaliteitsborging } & 24\end{array}$

$\begin{array}{lr}\text { Literatuur } & \mathbf{2 5}\end{array}$

$\begin{array}{lr}\text { Verantwoording } & \mathbf{2 7}\end{array}$ 


\section{Samenvatting}

Ieder voorjaar inventariseert Wageningen Marine Research in opdracht van het ministerie van Landbouw, Natuur en Voedselkwaliteit het kokkelbestand in de Waddenzee, Oosterschelde en Westerschelde. Op basis van de uitkomsten van de voorjaarssurvey wordt met behulp van groei- en sterftefactoren een schatting gemaakt van het kokkelbestand dat op 1 september aanwezig zal zijn (najaarsbestand). Op basis van dit najaarsbestand wordt door de vergunningverlener vastgesteld hoeveel kokkels opgevist mogen worden.

In de berekening van het najaarsbestand wordt gewerkt met gemiddelde waarden voor groei en sterfte tijdens de zomermaanden. Aangenomen wordt dat in de periode van 1 mei tot 1 september $28 \%$ van de kokkels een natuurlijke dood sterft. In de zomer van 2018 en 2019 is echter grootschalige kokkelsterfte opgetreden in de Oosterschelde en Waddenzee. Vermoedelijk had dit te maken met het optreden van hoge temperaturen op de droogvallende platen waar kokkels zich ingraven en overtijen tijdens laagwater.

In 2019 is dit project gestart met als doel het verbeteren van de schatting van het najaarsbestand op basis van de voorjaarsbemonstering. In 2020 is het doel aangepast naar het onderzoeken van zomersterfte onder kokkels in relatie tot de droogvalduur en gemeten temperaturen in het sediment. Om de relatie met temperatuur te kunnen onderzoeken, is het project gekoppeld aan een ander project (BO43 NAGW ZWD 2020, deelproject Hittestress) dat WMR uitvoert in opdracht van het Ministerie van Landbouw, Natuur en Voedselkwaliteit en waarbinnen onderzoek is gedaan aan het verloop van temperaturen in de bodem, in relatie tot droogvalduur, de luchttemperatuur, instraling door de zon en sedimenttype. In voorliggend rapport zijn de methoden die in 2019 en 2020 zijn toegepast voor het meten van sterfte in de Oosterschelde vastgelegd en de gemeten sterftecijfers gerapporteerd. Daarnaast is een literatuuronderzoek uitgevoerd naar wat bekend is over kokkelsterfte in relatie tot hoge temperaturen.

In 2019 was de sterfte gemiddeld genomen voor de 1 -jarige kokkels in de gehele Oosterschelde $5 \%$, voor de 2-jarige $23 \%$ en voor de meerjarige $87 \%$. In 2020 is kokkelsterfte over de zomer uitzonderlijk hoog gebleken. Met een sterfte van $95 \%$ onder de 1 -jarige kokkels en $81 \%$ onder de 2 -jarige kokkels, lag de sterfte onder 1 en 2-jarigen hoger dan voor meerjarige kokkels (sterfte van 68\%) en hoger dan de gemiddelde zomersterfte in de Oosterschelde ( $28 \%$, over een heel jaar is de gemiddelde sterfte ca. $60 \%$ ). De locatie Roggenplaat vertoonde de laagste sterftecijfers, terwijl locaties Oesterdam en Dortsman beide hoge sterftecijfers vertoonden, ondanks hun geografisch contrasterende ligging, sedimentsamenstelling en daarmee samenhangende temperatuurverloop. Mogelijk heeft dit te maken met het aantal uur dat de temperatuur 's nachts onder de $23^{\circ} \mathrm{C}$ kwam tijdens de hittegolf. Dit aantal uur ligt veel hoger op de Roggenplaat (202 uur) dan op de andere locaties (83 uur voor Dortsman en 134 uur voor Oesterdam).

Met de huidige klimaatverandering zullen luchttemperaturen stijgen en worden extremere temperaturen en meer hittegolven verwacht. Als gevolg zal de watertemperatuur ook stijgen en mogelijk ook al eerder in de zomer zijn afkoelende werking verliezen. Daardoor zouden kokkels langer blootgesteld zijn aan voor hen suboptimale temperaturen, waarbij ze verminderd actief zijn en wat mogelijk hun fitness vermindert. Dit effect zal dan het grootst worden geacht in het oostelijke deel van de Oosterschelde, waar het water langer verblijft, eerder en hoger opwarmt en meer slibrijke sedimenten te vinden zijn. Met de huidige kennis is echter niet te voorspellen hoe de kokkelpopulatie in de Oosterschelde zal veranderen als gevolg van klimaatverandering. 


\section{Inleiding}

\subsection{Achtergrond}

Jaarlijks wordt ten behoeve van de kokkelvisserij het bestand aan kokkels in de Waddenzee, Oosterschelde en Westerschelde geïnventariseerd. Deze inventarisatie vindt plaats in opdracht van het Ministerie van Landbouw, Natuur en Voedselkwaliteit (LNV) en wordt uitgevoerd door Wageningen Marine Research (WMR). De bestandsschatting wordt uitgevoerd in het voorjaar (april-juni). Op basis van de uitkomsten van deze voorjaarssurvey wordt met behulp van groei- en sterftefactoren (vastgesteld in de periode 1992-2000) een schatting gemaakt van het kokkelbestand dat op 1 september aanwezig zal zijn (najaarsbestand). Op basis van dit najaarsbestand wordt door de vergunningverlener vastgesteld hoeveel kokkels opgevist mogen worden (het 'quotum'). De methode voor berekening van het kokkelbestand op 1 september wordt meer uitgebreid beschreven door van Asch et al. (2019).

\subsection{Probleemstelling}

In de berekening van het najaarsbestand wordt gewerkt met gemiddelde waarden voor groei en sterfte tijdens de zomermaanden (van Asch et al., 2019). Aangenomen wordt dat in de periode van 1 mei tot 1 september $28 \%$ van de kokkels een natuurlijke dood sterft. Deze waarde is vastgesteld als een gemiddelde over meerdere jaren. Uit een evaluatie van deze methode bleek dat de zomersterfte met deze methode niet structureel wordt over- of onderschat (Kamermans et al., 2003). Echter, in de zomer van 2018 en 2019 heeft zich een uitzonderlijk omvangrijke kokkelsterfte voorgedaan in de Waddenzee, Oosterschelde en Westerschelde, waarschijnlijk als gevolg van de warme zomer. Op veel plaatsen waren de platen bezaaid met stervende en pas gestorven kokkels, al dan niet met het vlees nog in de schelpen. Deze uitzonderlijk hoge sterfte kan ertoe leiden dat het najaarsbestand (sterk) wordt overschat. Dit zou consequenties kunnen hebben voor scholeksters indien het visserij quotum niet naar beneden zou worden bijgesteld. In september 2018 is daarom het kokkelbestand opnieuw bemonsterd en op basis daarvan zijn de visserijquota met $80 \%$ verlaagd (Troost \& Van Asch, 2018). In 2019 zijn de quota op basis van expert judgement met $65 \%$ verlaagd (Troost, 2019). Deze hoge sterfte kan vaker verwacht worden als gevolg van klimaatverandering waardoor strengere winters en extremere zomers frequenter voor zullen komen. Onduidelijk is of de gemiddelde sterftefactoren die 20 jaar geleden zijn bepaald, nog steeds representatief zijn. Ook is onduidelijk wat precies de relatie is tussen hoge temperaturen en sterfte onder kokkels.

\subsection{Doelstelling}

Het 2-jarige project is uitgevoerd binnen het kennisbasis programma gekoppeld aan de wettelijke onderzoekstaken op het gebied van visserij (KB-WOT, KB-36-002-012), gefinancierd door het ministerie van LNV.

Het project is in 2019 opgestart met als doel: het verbeteren van de schatting van het najaarsbestand op basis van de voorjaarsbemonstering. Om na te kunnen gaan of de huidige sterfte afwijkt van de waarde die in de periode $1992-2000$ is vastgesteld, en om in te kunnen schatten hoe klimaatbestendig de bestandsschatting voor september is, is sterfte gedurende de zomermaanden onderzocht op vier locaties in de Oosterschelde.

In 2020 is het doel aangepast naar: het onderzoeken van zomersterfte onder kokkels in relatie tot de droogvalduur (= de periode dat de locatie rond laagwater droogvalt) en gemeten temperaturen in het sediment. Om dit te kunnen onderzoeken is het project gekoppeld aan een ander project waarbinnen onderzoek is gedaan aan het verloop van temperaturen in de bodem, in relatie tot droogvalduur, de 
luchttemperatuur, instraling door de zon en sedimenttype. Dit project is het Hittestress project (BO43 NAGW ZWD 2020, deelproject Hittestress) dat WMR uitvoert in opdracht van het Ministerie van Landbouw, Natuur en Voedselkwaliteit. In voorliggend rapport wordt sterfte behandeld. De uitgebreide koppeling aan de abiotische variabelen gemeten binnen het 'Hittestress' project wordt gemaakt in het eindrapport van dat project (Suykerbuyk et al., 2021).

Het doel van dit rapport is het vastleggen van de methoden die in 2019 en 2020 zijn toegepast voor het meten van sterfte in de Oosterschelde. Uit de resultaten wordt berekend welk sterftepercentage is opgetreden onder de verschillende leeftijdsklassen. Deze gemeten sterfte wordt vergeleken met de metingen in de periode 1992-2000. Tot slot is een literatuuronderzoek gedaan naar kokkelsterfte in relatie tot hoge temperaturen.

\subsection{Leeswijzer}

In hoofdstuk 2 wordt de methodiek beschreven voor het bemonsteren van de kokkelvakken. In hoofdstuk 3 zijn de resultaten van het onderzoek weergegeven. In hoofdstuk 4 wordt beschreven wat er op basis van literatuuronderzoek bekend is over kokkelsterfte in relatie tot hoge temperaturen. Tot slot bevat hoofdstuk 5 de discussie waarbij tevens de koppeling wordt gelegd met het Hittestress project. 


\section{Methoden}

\subsection{Locaties}

\section{1 .12019}

In het voor- en najaar van 2019 zijn bemonsteringen uitgevoerd op vier locaties in de Oosterschelde (Figuur 1, locatie $1 \mathrm{t} / \mathrm{m} \mathrm{4}$ ). In het voorjaar ging de bemonstering van start op 28 maart, waarbij de Oesterdam werd bemonsterd (Tabel 1). Op 9 april zijn de Slikken van den Dortsman bemonsterd en op 18 april de Roggenplaat. De Krabbenkreek is op 19 april bemonsterd. In het najaar zijn de Slikken van den Dortsman op 5 september bemonsterd, de Oesterdam en Krabbenkreek op 12 september en de Roggenplaat op 13 september.

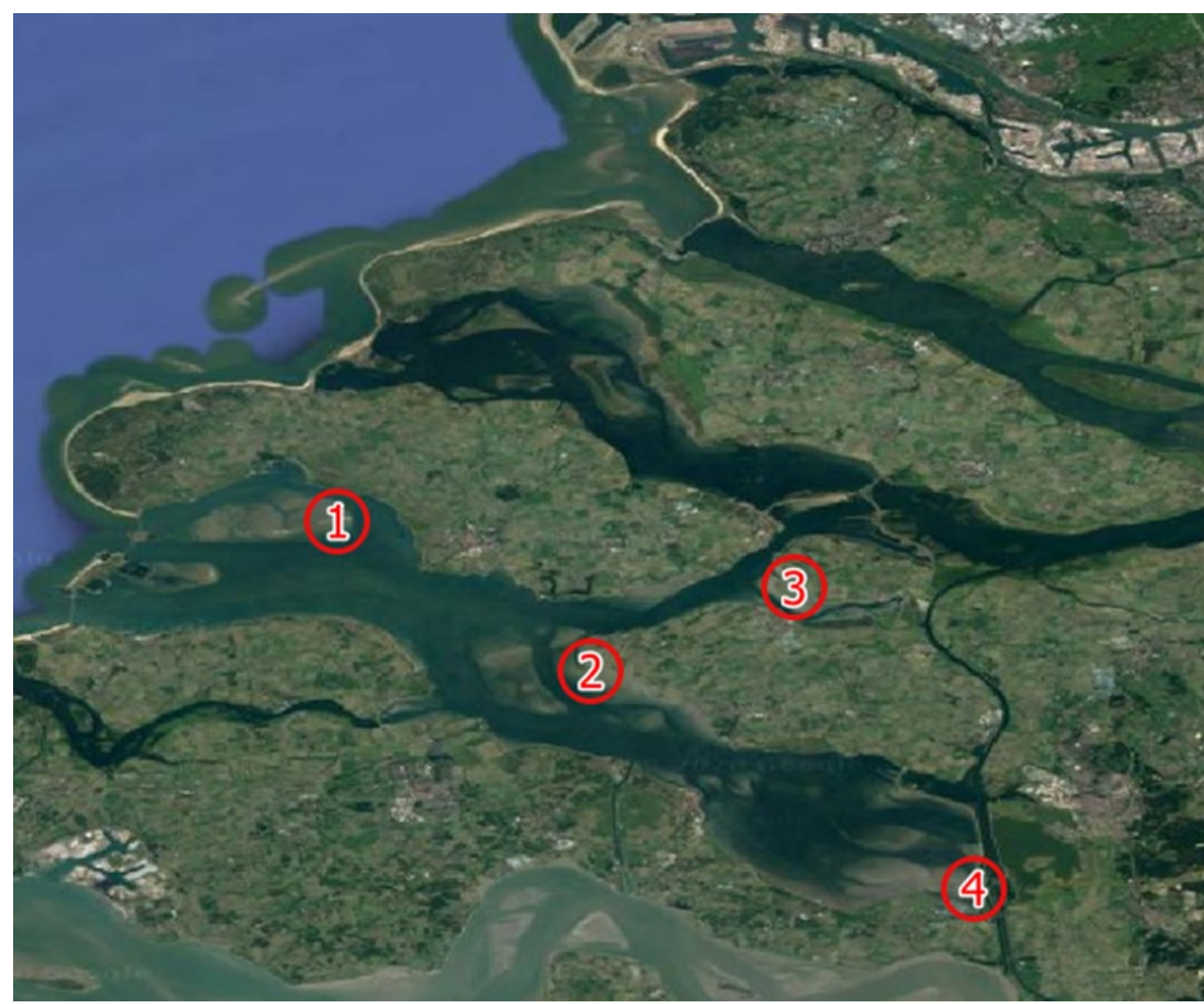

Figuur 1. Overzicht van de bemonsterlocaties. 1) Roggenplaat; 2) Slikken van den Dortsman; 3) Krabbenkreek; 4) Oesterdam. Locatie 1, 2, 3 en 4 zijn bemonsterd in 2019 en locatie 1, 2 en 4 zijn bemonsterd in 2020. 
Tabel 1. Bemonstering 2019 en 2020.

\begin{tabular}{|c|c|c|c|c|}
\hline Jaar & Locatie & $\begin{array}{l}\text { Datum bemonstering } \\
\text { voorjaar }\end{array}$ & $\begin{array}{l}\text { Datum bemonstering } \\
\text { najaar }\end{array}$ & $\begin{array}{l}\text { Dagen tussen voor- en } \\
\text { najaarsbemonstering }\end{array}$ \\
\hline \multirow{4}{*}{ 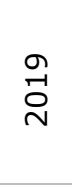 } & Roggenplaat & 18 april & 13 september & 149 dagen \\
\hline & Slikken van Den Dorstman & 9 april & 5 september & 150 dagen \\
\hline & Oesterdam & 28 maart & 12 september & 169 dagen \\
\hline & Krabbenkreek & 19 april & 12 september & 147 dagen \\
\hline \multirow{3}{*}{$\stackrel{\text { ָ }}{\text { D }}$} & Roggenplaat & 11 mei & 10 september & 123 dagen \\
\hline & Slikken van Den Dorstman & 28 april & 9 september & 135 dagen \\
\hline & Oesterdam & 13 mei & 3 september & 114 dagen \\
\hline
\end{tabular}

Deze locaties zijn geselecteerd op basis van toegankelijkheid vanaf de kant en aanwezigheid van kokkels op basis van de herbemonstering in het najaar van 2018. Per locatie zijn vier vakken uitgezet om te bemonsteren (Figuur 2).

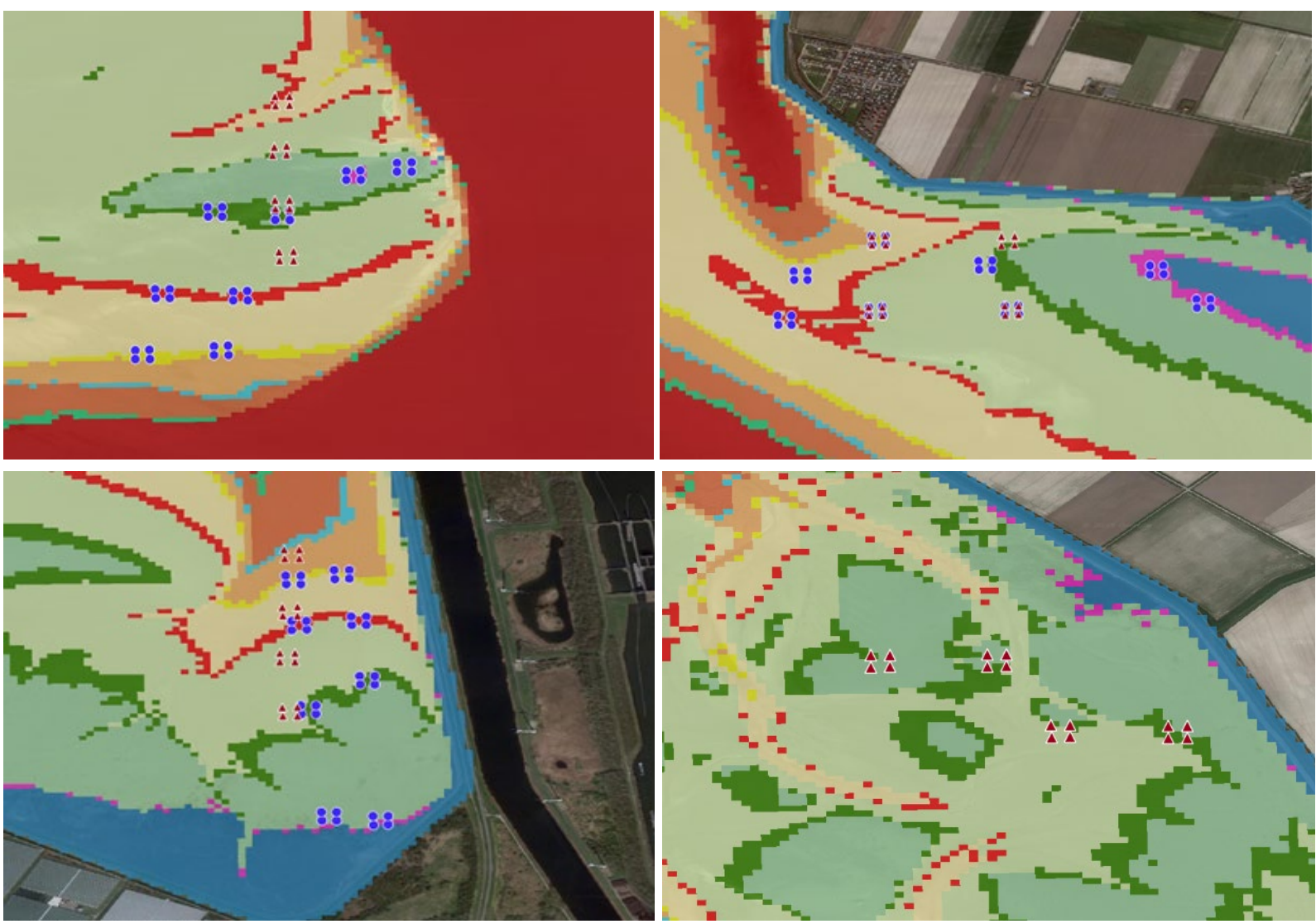

Figuur 2. Gedetailleerd overzicht van de kokkelvakken per locatie. Kaarten zijn Noord georiënteerd en niet op dezelfde schaal. Linksboven: Roggenplaat. Rechtsboven: Slikken van den Dortsman. Linksonder: Oesterdam. Rechtsonder: Krabbenkreek. Rode driehoekjes zijn hoekpunten van de kokkelvakken in 2019 en blauwe rondjes hoekpunten van kokkelvakken 2020. Let op kokkelvakken die over elkaar heen liggen. De kleuren op de achtergrond verwijzen naar de droogvalduur. De kokkelvakken liggen op verschillende droogvalduren: Roze: 7981\%. Donkergroen: 65-67\%. Rood: 51-52\%. Geel: 35-37\%. 


\section{$2.1 .2 \quad 2020$}

In het voor- en najaar van 2020 zijn bemonsteringen uitgevoerd op drie locaties in de Oosterschelde (Figuur 1). De voorjaarsbemonstering ging van start op 28 april, op locatie Slikken van den Dortsman, op 11 mei is locatie Roggenplaat bemonsterd en op 13 mei locatie Oesterdam (Figuur 2, Tabel 1). In het najaar zijn dezelfde locaties bemonsterd: 3 september Oesterdam, 9 september Slikken van den Dortsman en 10 september Roggenplaat.

Deze locaties zijn geselecteerd op basis van toegankelijkheid vanaf de kant en aanwezigheid van kokkels op basis van de WOT survey in het voorjaar van 2019. Per locatie in de Oosterschelde zijn acht vakken geselecteerd op vier verschillende droogvalduren, twee replica's per droogvalduur (Figuur 2). Er is gekozen voor droogvalduren $36 \%, 52 \%, 66 \%$ en $80 \%$.

\subsection{Monstername}

De locaties van de hoekpunten van elk vak zijn voorafgaand aan het veldwerk in een GPS gezet, zodat in het veld de hoekpunten met een bamboestok gemarkeerd konden worden. Elk kokkelvak had een oppervlakte van $40 \mathrm{~m}$ bij $40 \mathrm{~m}$. Per vak zijn met behulp van een steekbuis (diameter 10,4 cm) 50 monsters uitgestoken van ca. $10 \mathrm{~cm}$ diep. De 50 steken werden gelijkmatig over het kokkelvak verspreid door raaien te lopen door het vak en om de vijf meter een monster te nemen (Figuur 3). Per vak zijn op deze manier zeven raaien gelopen met elk zeven punten en voor het $50^{\text {ste }}$ monster één extra punt op het eind.

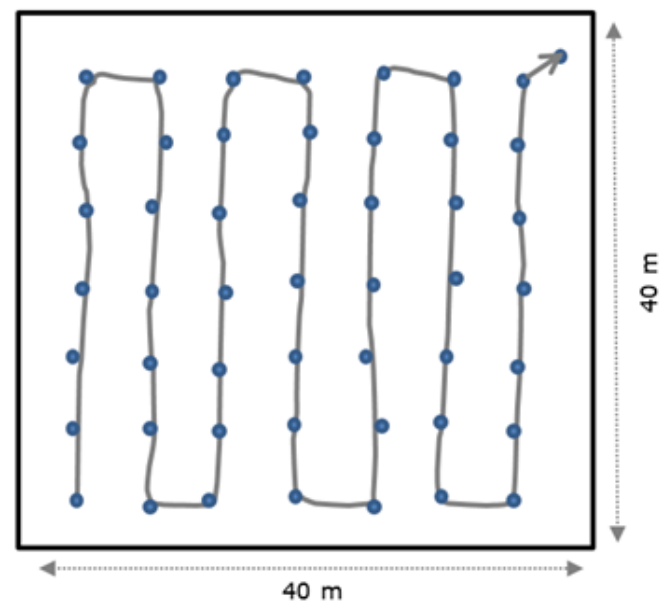

Figuur 3. Kokkelvak met 50 bemonsteringspunten.

De monsters werden in een grote zeefton ( $2 \mathrm{~mm}$ maaswijdte) verzameld. Tussendoor werd het sediment gezeefd zodat de ton niet te zwaar werd. Dit gebeurde in een klein laagje water zodat het sediment gemakkelijker wegspoelde. Nadat alle 50 steekbuizen genomen waren, werd nogmaals zorgvuldig gezeefd zodat zoveel mogelijk sediment was weggespoeld. Het achtergebleven materiaal werd verzameld in een plastic zak waarin een label zat met locatienummer. Vervolgens werd het zakje gesloten en in de rugzak gedaan. De stokjes werden van de hoekpunten gehaald en de GPS ingesteld op het volgende kokkelvak. Nadat alle vakken bemonsterd waren, werden de zakken in een koelbox met koelelementen geplaatst en vervoerd naar het laboratorium. Tijd tussen bemonstering van het eerste vak en het plaatsen van de samples in de koelbox, was ca. 4 uur. 


\subsection{Labverwerking}

De monsters werden in de ochtend en/of middag verzameld in het veld en werden daarna teruggebracht naar het lab in een koelbox met koelelementen. Indien mogelijk werden de monsters nog dezelfde dag verwerkt. Indien dat niet mogelijk was, vond de verwerking de volgende dag plaats en werden de monsters bewaard in de koelbox die afgesloten in een koelcel $\left(4^{\circ} \mathrm{C}\right)$ werd geplaatst.

In het lab werd een monster uit de koelbox gehaald en uitgeschud boven een bak. Uit het monster werden de kokkels verzameld en apart gelegd. Ook kapotte schelpen waar nog wel vlees in zat en het slot zichtbaar was, werden apart gehouden. Doordat alleen schelpen werden bewaard waarbij het slot zichtbaar was, werden kapotte schelpen niet dubbel geteld. Nadat het hele monster nauwkeurig was doorzocht op kokkels, werd het overige materiaal weggegooid. Daarna werden de levende kokkels gesorteerd op leeftijd aan de hand van groeiringen op de schelp. De kapotte kokkels (waar wel nog vlees in zat en het slot zichtbaar was) werden eveneens op leeftijd gesorteerd en apart gehouden van de intacte individuen. Daarna werden de kokkels per jaarklasse geteld. Ook de kapotte individuen werden per jaarklasse geteld. Vervolgens werd het versgewicht per jaarklasse bepaald en genoteerd door alle individuen van dezelfde jaarklassen in een bakje te verzamelen en te wegen op een weegschaal. Kapotte individuen werden niet gewogen.

Vervolgens werd koel zeewater toegevoegd aan het bakje waardoor de kokkels de mogelijkheid kregen om water dat verloren was gegaan door de lange droogstand op te nemen in hun mantelholte (drinken). Nadat activiteit in de vorm van klepbewegingen was waargenomen (na ongeveer een half uur), werden ze uit het water gehaald en werden de kokkels opnieuw per leeftijdsklasse gewogen. Ook dit gewicht werd genoteerd. Op deze manier kon bepaald worden hoeveel water er uit de schelpen was gelopen voordat ze verwerkt werden.

Alle gegevens werden genoteerd in een Access database. Nadat alle metingen uitgevoerd waren, werden de kokkels per leeftijdsklasse apart in een zakje bewaard. De zakjes werden vervolgens in één zak verzameld, zodat alle kokkels van één vak één monster vormden, maar de leeftijdsklasse wel nog apart zijn gehouden. Het zakje werd vervolgens in een krat in de vriezer bewaard. Op deze manier werden alle monsters (twee keer 24 monsters) verwerkt. De monsters zijn opgeslagen in de vriezer om eventueel later nog asvrij drooggewichten te kunnen bepalen, zoals in 2019 is gedaan voor een deel van de monsters.

\subsection{Sterfteanalyse}

Het sterftepercentage in de periode tussen de voor- en najaarbemonstering is per leeftijdsklasse (1jarig, 2-jarig en meerjarig) berekend uit het aantal kokkels in het voorjaar en najaar, als:

$$
M=100-\left(100 \times \frac{d_{n j}}{d_{v j}}\right)
$$

Waarbij: $\quad M=$ mortaliteit (sterfte in \%)

$d_{n j}=$ gemiddeld aantal kokkels in het najaar

$d_{v j}=$ gemiddeld aantal kokkels in het voorjaar

Het sterftepercentage is per locatie bepaald als het totaal aantal kokkels in de acht vakken vanwege grote variatie tussen de vakken. Vervolgens is per locatie de sterfte uitgesplitst naar droogvalduur (enkel voor 2020). Die is op eenzelfde manier berekend, namelijk uit het verschil tussen voor- en najaar van totaal aantal kokkels per droogvalduur per locatie. 


\section{Resultaten}

\subsection{Sterfte in 2019}

Op drie van de vier locaties in de Oosterschelde was in het najaar een hoger aantal 1-jarige kokkels aangetroffen dan in het voorjaar (Figuur 4). Een mogelijke oorzaak hiervan is dat stressringen zijn aangezien voor jaarringen waardoor 1-jarige kokkels in het voorjaar zijn geclassificeerd als 2-jarige kokkels. Daardoor is het aantal 1-jarigen in het voorjaar mogelijk onderschat. Dit heeft geleid tot een negatieve sterfte en is in figuur 4 als 0 weergegeven. Op de Oesterdam was het aantal 1 -jarige kokkels in het najaar lager dan in het voorjaar, wat heeft geleid tot een sterfte van bijna $40 \%$. Voor de 2-jarige kokkels varieerde de sterfte van bijna $30 \%$ op de Slikken van den Dortsman tot $100 \%$ op de Oesterdam en Krabbenkreek. Op de Roggenplaat bleek een negatieve sterfte, met meer kokkels in het najaar dan in het voorjaar. Het aantal meerjarige kokkels is op alle locaties afgenomen, variërend van $50 \%$ tot $100 \%$. Gemiddeld genomen was de sterfte voor de 1 -jarige kokkels in de gehele Oosterschelde $5 \%$, voor de 2 -jarige $23 \%$ en voor de meerjarige $87 \%$ (Tabel 2 ).

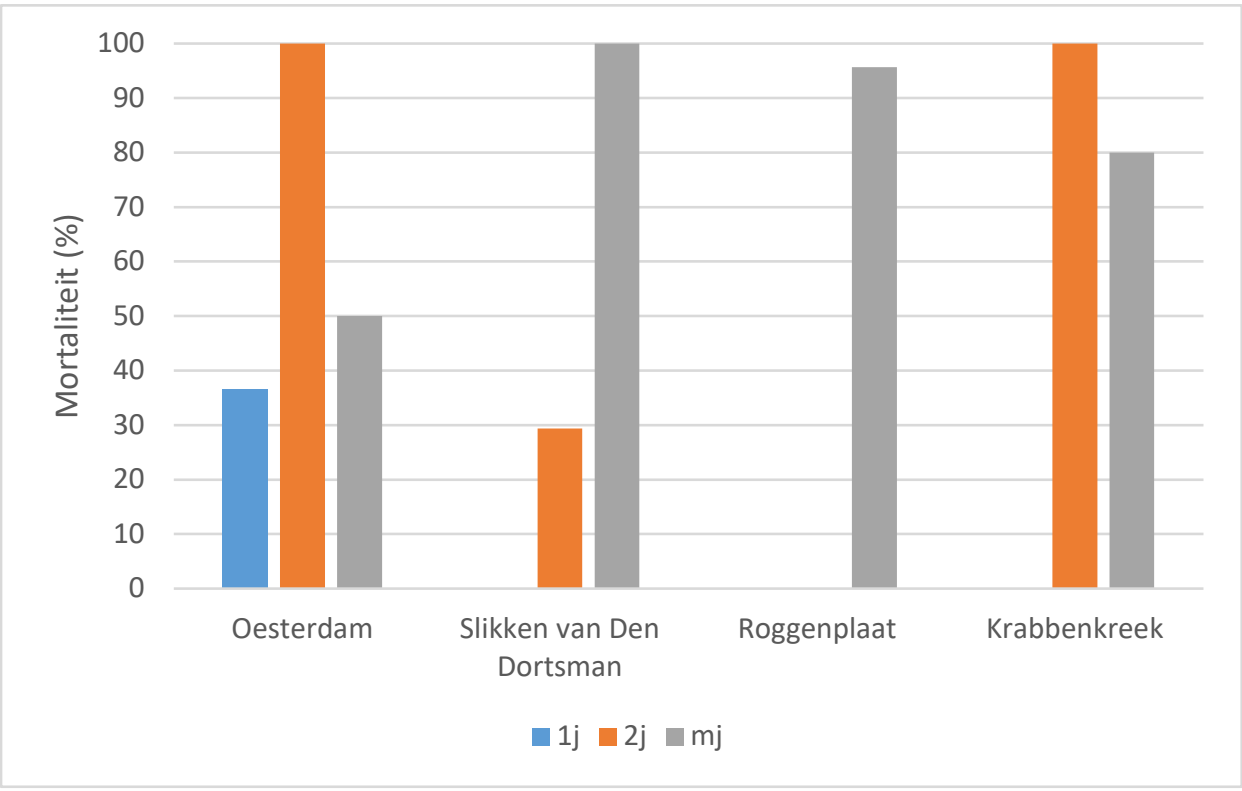

Figuur 4. Sterfte (\%) per locatie in de Oosterschelde in 2019. Per locatie is de sterfte berekend uit het totale aantal kokkels uit de acht vakken. Negatieve sterfte is op 0 gezet. 1j: 1-jarige kokkels, 2j: 2-jarige kokkels, mj: meerjarige kokkels. 
Tabel 2. Totaal aantal kokkels per locatie in het voorjaar ( $v j)$ en najaar ( $n j)$ van 2019, en de daaruit berekende sterfte. Weergegeven per leeftijdsklasse $(\mathrm{nb}=$ niet bepaald) en voor het totaal van alle leeftijdsklassen samen (zonder de 0-jarigen).

\begin{tabular}{|c|c|c|c|c|c|c|c|c|c|c|c|c|c|c|}
\hline \multirow[b]{2}{*}{ Locatie } & \multirow{2}{*}{$\begin{array}{c}\text { 0-jarig } \\
\mathbf{n j} \\
(n) \\
\end{array}$} & \multicolumn{3}{|c|}{ 1-jarig } & \multicolumn{3}{|c|}{ 2-jarig } & \multicolumn{3}{|c|}{ meerjarig } & \multirow{2}{*}{$\begin{array}{c}\mathbf{n b} \\
\mathbf{v j} \\
(n) \\
\end{array}$} & \multicolumn{3}{|c|}{ totaal } \\
\hline & & $\begin{array}{l}\mathbf{v j} \\
(n)\end{array}$ & $\begin{array}{l}\mathbf{n j} \\
(n)\end{array}$ & $\begin{array}{c}\text { sterfte } \\
(\%)\end{array}$ & $\begin{array}{l}\mathbf{v j} \\
(n)\end{array}$ & $\begin{array}{l}\mathbf{n j} \\
(n) \\
\end{array}$ & $\begin{array}{c}\text { sterfte } \\
(\%)\end{array}$ & $\begin{array}{l}\mathbf{v j} \\
(n)\end{array}$ & $\begin{array}{l}\mathbf{n j} \\
(n)\end{array}$ & $\begin{array}{c}\text { sterfte } \\
(\%)\end{array}$ & & $\begin{array}{l}\mathbf{v j} \\
(n)\end{array}$ & $\begin{array}{l}\mathbf{n j} \\
(n)\end{array}$ & $\begin{array}{c}\text { sterfte } \\
(\%) \\
\end{array}$ \\
\hline Oosterschelde & 618 & 809 & 769 & 5 & 35 & 27 & 23 & 38 & 5 & 87 & 4 & 886 & 801 & 10 \\
\hline Oesterdam & 163 & 292 & 185 & 37 & 10 & 0 & 100 & 6 & 3 & 50 & 0 & 308 & 188 & 39 \\
\hline Slikken vd Dortsman & 293 & 200 & 218 & -9 & 17 & 12 & 29 & 4 & 0 & 100 & 1 & 222 & 230 & -4 \\
\hline Roggenplaat & 33 & 105 & 125 & -19 & 5 & 15 & -200 & 23 & 1 & 96 & 3 & 136 & 141 & -4 \\
\hline Krabbenkreek & 129 & 212 & 241 & -14 & 3 & 0 & 100 & 5 & 1 & 80 & 0 & 220 & 242 & -10 \\
\hline
\end{tabular}

\subsection{Sterfte in 2020}

De kokkelsterfte in de zomer van 2020 voor alle leeftijdsklasse samen varieerde van $62 \%$ op de Roggenplaat, tot $94 \%$ op de Oesterdam (Tabel 3). De totale sterfte op de Slikken van den Dortsman was $92 \%$.

Binnen alle leeftijdsklassen nam het aantal kokkels af tussen het voorjaar en najaar van 2020 (Figuur 5). De sterfte onder de 1 -jarige kokkels varieerde van ruim $80 \%$ op de Roggenplaat tot $95 \%$ en $96 \%$ op respectievelijk de Slikken van den Dortsman en Oesterdam. Ook de sterfte onder 2-jarige kokkels bleek het hoogst op de Slikken van den Dorstman en Oesterdam, met respectievelijk $89 \%$ en $91 \%$. De sterfte op de Roggenplaat was 56\%. Onder de meerjarige kokkels was de sterfte op de Slikken van Den Dorstman lager dan voor de 1 - en 2-jarige kokkels, namelijk $41 \%$. De sterfte op de Roggenplaat en Oesterdam waren respectievelijk $78 \%$ en $90 \%$.

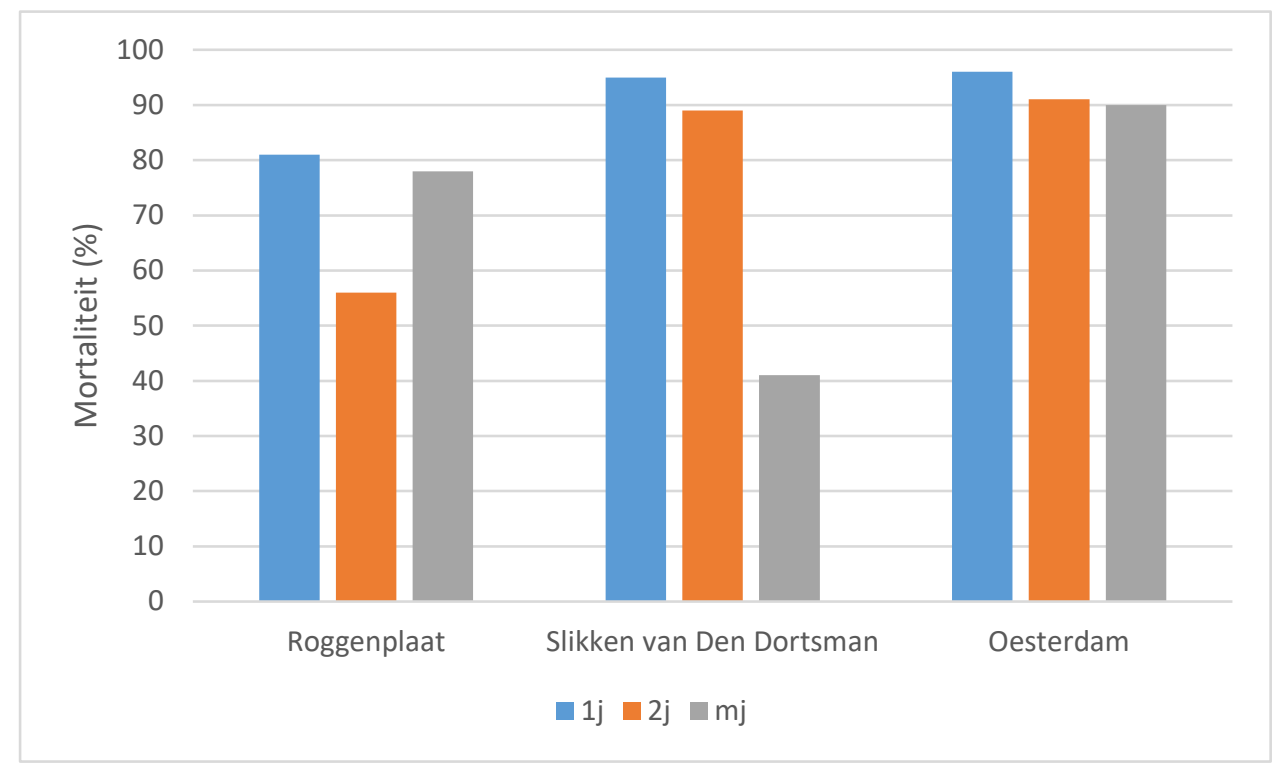

Figuur 5. Sterfte (\%) per locatie in de Oosterschelde in 2020. Per locatie is de sterfte berekend uit het totale aantal kokkels uit de acht vakken. 1j: 1-jarige kokkels, $2 \mathrm{j}$ : 2 jarige kokkels, mj: meerjarige kokkels. 
De sterfte uitgesplitst naar droogvalduur per locatie is weergegeven in Figuur 6. Op de Oesterdam en Roggenplaat was de sterfte het laagst bij een droogvalduur van 36\%. Op de Slikken van den Dortsman was de sterfte voor alle droogvalduren hoger dan $87 \%$. Op de Roggenplaat werd de hoogste sterfte waargenomen bij een droogvalduur van $66 \%$, namelijk $79 \%$.

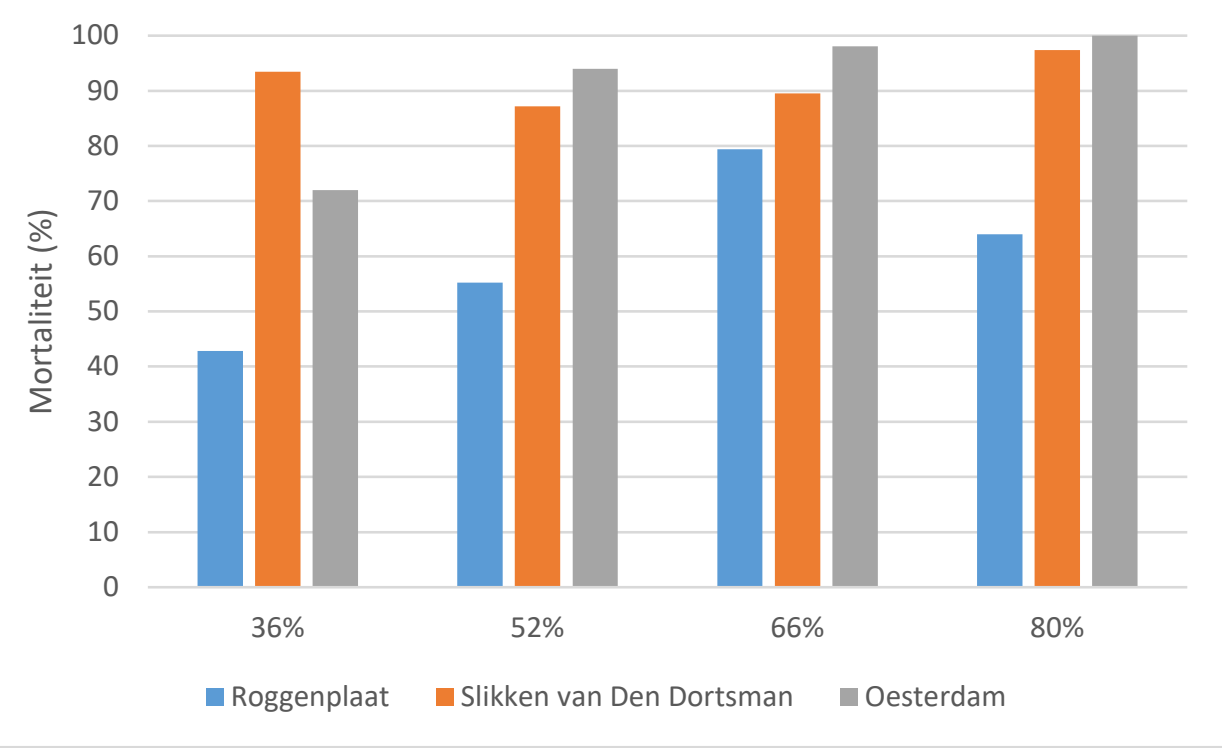

Figuur 6. Sterfte (\%) in 2020 uitgesplitst naar droogvalduur op drie locaties in de Oosterschelde in 2020. Per locatie is de sterfte berekend uit het totale aantal kokkels uit de acht vakken.

De gemiddelde sterfte varieerde van $84 \%$ (droogvalduur $52 \%$ ) tot $90 \%$ (droogvalduur $36 \%$ en $66 \%$ ) voor alle leeftijdsklasse samen (Figuur 7). De sterfte van kokkels onder een droogvalduur van $80 \%$ bedroeg $88 \%$. Onder 1 -jarige kokkels was voor alle droogvalduren hoger dan $90 \%$. Onder 2 -jarige en meerjarige kokkels varieerde de sterfte van $70 \%$ tot bijna $90 \%$, waarbij de sterfte het hoogst was bij een droogvalduur van $66 \%$.

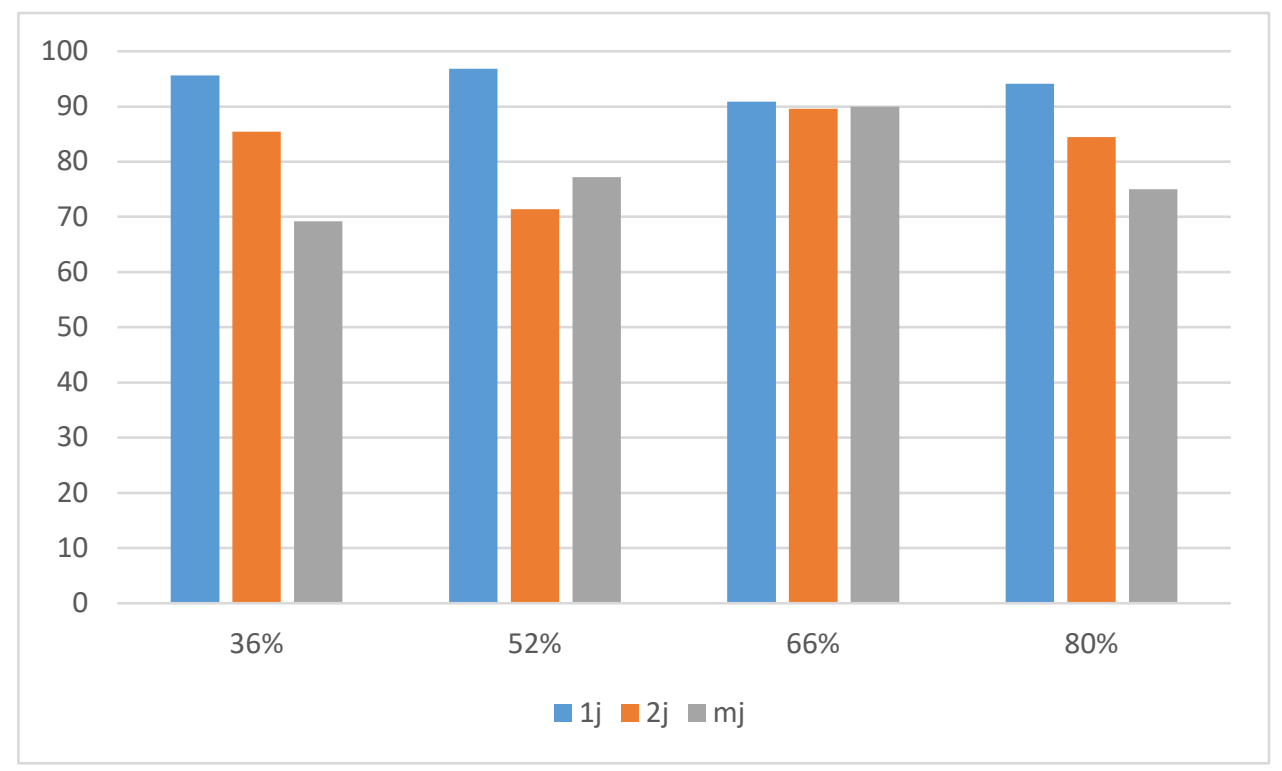

Figuur 7. Sterfte (\%) uitgesplitst naar droogvalduur per leeftijdsklasse voor alle locaties in de Oosterschelde in 2020. 1j: 1-jarige kokkels, 2j: 2-jarige kokkels, mj: meerjarige kokkels. 


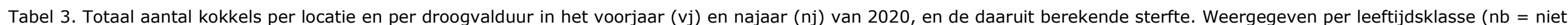
bepaald) en voor het totaal van alle leeftijdklassen samen (zonder de 0 -jarigen).

\begin{tabular}{|c|c|c|c|c|c|c|c|c|c|c|c|c|c|c|c|}
\hline $\begin{array}{l}\text { Locatie } \\
\qquad \text { Droogvalduur }\end{array}$ & & $\begin{array}{c}\text { 0-jarig } \\
\text { nj } \\
(n)\end{array}$ & $\begin{array}{l}\mathbf{v j} \\
(n)\end{array}$ & $\begin{array}{l}\text { 1-ja } \\
\text { nj } \\
(n)\end{array}$ & $\begin{array}{c}\text { sterfte } \\
(\%)\end{array}$ & $\begin{array}{l}\mathbf{v j} \\
(n)\end{array}$ & $\begin{array}{l}\text { 2-jar } \\
\text { nj } \\
(n)\end{array}$ & $\begin{array}{c}\text { sterfte } \\
(\%)\end{array}$ & $\begin{array}{l}\mathbf{v j} \\
(n)\end{array}$ & $\begin{array}{c}\text { meer } \\
\text { nj } \\
(n)\end{array}$ & $\begin{array}{l}\text { rig } \\
\text { sterfte } \\
(\%)\end{array}$ & $\begin{array}{l}\mathbf{n b} \\
\mathbf{v j} \\
(n)\end{array}$ & $\begin{array}{l}\mathbf{v j} \\
(n)\end{array}$ & $\begin{array}{l}\text { tota } \\
\text { nj } \\
(n) \\
\end{array}$ & $\begin{array}{c}\text { sterfte } \\
(\%)\end{array}$ \\
\hline Roggenplaat & & 8 & 27 & 5 & 81 & 183 & 81 & 56 & 40 & 9 & 78 & 0 & 250 & 95 & 62 \\
\hline & $36 \%$ & 1 & 1 & 2 & -100 & 6 & 5 & 17 & 7 & 1 & 86 & 0 & 14 & 8 & 43 \\
\hline & $52 \%$ & 0 & 3 & 1 & 67 & 114 & 57 & 50 & 26 & 6 & 77 & 0 & 143 & 64 & 55 \\
\hline & $66 \%$ & 5 & 18 & 1 & 94 & 45 & 12 & 73 & 5 & 1 & 80 & 0 & 68 & 14 & 79 \\
\hline & $80 \%$ & 2 & 5 & 1 & 80 & 18 & 7 & 61 & 2 & 1 & 50 & 0 & 25 & 9 & 64 \\
\hline Slikken van den Dortsman & & 20 & 386 & 18 & 95 & 224 & 24 & 89 & 17 & 10 & 41 & 0 & 627 & 52 & 92 \\
\hline & $36 \%$ & 13 & 214 & 7 & 97 & 125 & 12 & 90 & 12 & 4 & 67 & 0 & 351 & 23 & 93 \\
\hline & $52 \%$ & 2 & 73 & 0 & 100 & 55 & 11 & 80 & 5 & 6 & -20 & 0 & 133 & 17 & 87 \\
\hline & $66 \%$ & 1 & 70 & 10 & 86 & 35 & 1 & 97 & 0 & 0 & NA & 0 & 105 & 11 & 90 \\
\hline & $80 \%$ & 4 & 29 & 1 & 97 & 9 & 0 & 100 & 0 & 0 & NA & 0 & 38 & 1 & 97 \\
\hline Oesterdam & & 130 & 307 & 12 & 96 & 244 & 16 & 93 & 16 & 4 & 75 & 0 & 567 & 32 & 94 \\
\hline & $36 \%$ & 6 & 12 & 1 & 92 & 149 & 3 & 98 & 5 & 3 & 40 & 0 & 166 & 7 & 72 \\
\hline & $52 \%$ & 106 & 241 & 9 & 96 & 80 & 13 & 84 & 11 & 1 & 91 & 0 & 332 & 23 & 94 \\
\hline & $66 \%$ & 18 & 54 & 2 & 96 & 14 & 0 & 100 & 0 & 0 & NA & 0 & 68 & 2 & 98 \\
\hline & $80 \%$ & 0 & 0 & 0 & NA & 1 & 0 & 100 & 0 & 0 & NA & 0 & 1 & 0 & 100 \\
\hline
\end{tabular}




\section{Literatuur review}

In dit hoofdstuk wordt een overzicht gegeven van wat er in de literatuur bekend is over kokkelsterfte in relatie tot hoge temperaturen.

\subsection{Optimale temperatuurrange}

Temperatuur is een van de belangrijkste factoren die van invloed zijn op de geografische verspreiding van tweekleppigen. Het heeft effect op fysiologische processen, reproductie, groei en populatiedynamica. Welke temperaturen optimaal zijn, is soortspecifiek en afhankelijk van de mogelijkheid van een soort om zich aan te passen aan bepaalde temperaturen (Compton et al., 2007; Gosling, 2003; Kordas et al., 2011).

Door Verdelhos et al. (2015) is een onderzoek uitgevoerd naar gedrag en overleving van Portugese kokkels bij temperaturen variërend van $5-35^{\circ} \mathrm{C}$. Activiteit van de kokkels werd beoordeeld op basis van vier gedragskenmerken: ingraven, activiteit van de sifon, activiteit van de voet en reactie op mechanische prikkels. Uit dit onderzoek bleek dat de activiteit van kokkels afnam naarmate de temperatuur meer afweek van hun optimale temperatuurrange $\left(20-23^{\circ} \mathrm{C}\right)$. De laagste activiteit werd waargenomen bij de meest extreme temperaturen. Daarnaast bleek dat de kokkels die werden blootgesteld aan temperaturen met een kleine afwijking van de optimale temperatuur in het begin hoge activiteit vertoonden, maar dat die afnam doorheen de tijd. Dit suggereert dat kokkels lange tijd kunnen overleven onder niet-optimale omstandigheden, maar dat ze niet in staat zijn hun normale gedrag in stand te houden, wat op den duur tot sterfte kan leiden. Uit het onderzoek bleek daarnaast dat geen sterfte optrad bij temperaturen van $5-23^{\circ} \mathrm{C}$, sterfte sterk toeneemt boven een temperatuur van $26^{\circ} \mathrm{C}$ en boven $32^{\circ} \mathrm{C}$ een sterfte van $100 \%$ optreedt, wat aantoont dat extreme warmte zelfs voor korte duur lethaal kan zijn. Bij een temperatuur van $29^{\circ} \mathrm{C}$ begon sterfte na 36 uur en na 99 uur bleek de helft van de kokkels gestorven. Bij een temperatuur van $32^{\circ} \mathrm{C}$ was $40 \%$ van de individuen dood na 48 uur en $100 \%$ na 84 uur. Bij de hoogst gemeten temperaturen $\left(35^{\circ} \mathrm{C}\right)$ waren alle kokkels dood binnen 6 uur. Uit dit onderzoek blijkt dus dat verhoogde temperaturen een negatief effect hebben op kokkels en dat extreem hoge temperaturen kunnen leiden tot sterfte. De optimumtemperatuur die gemeten is voor de Portugese kokkels is $20-23^{\circ} \mathrm{C}$ (Verdelhos et al., 2015). Het is echter onbekend of deze optimumtemperatuur ook geldt voor Nederlandse kokkels. Verdelhos et al. merken op dat klimaatverandering kan leiden tot hogere omgevingstemperaturen wat effect kan hebben op de optimum temperatuurrange en kritische temperatuurwaarden van kokkels. Indien de optimumtemperatuur inderdaad afhankelijk is van omgevingstemperatuur, is het mogelijk dat Nederlandse kokkels een lagere optimumtemperatuur hebben dan de genoemde $20-23^{\circ} \mathrm{C}$. Een onderzoek naar temperatuurtolerantie bij C. glaucum laat zien dat kokkels verzameld in de zomer en winter in Frankrijk en in de zomer in Ierland bij een maximale temperatuur van $40^{\circ} \mathrm{C}$ nog reactie vertonen op mechanische prikkels, terwijl kokkels verzameld in de winter in Ierland (met een lagere omgevingstemperatuur dan in de andere gebieden) reactie vertonen tot een maximale temperatuur van $35^{\circ} \mathrm{C}$ (Wilson \& Elkaim, 1997). Dat betekent dat deze kokkels zowel regionale verschillen als seizoensverschillen vertonen.

De kokkels in het onderzoek door Verdelhos et al. (2015) werden blootgesteld aan plotselinge temperatuurveranderingen. Hittegolven zorgen voor abrupte veranderingen in temperatuur waardoor kokkels niet genoeg tijd hebben om zich aan te passen (Gosling, 2004; Helmuth \& Hofmann, 2001; Lannig et al., 2006; Verdelhos et al., 2015). Dat kokkels een grotere kans hebben op overleving na acclimatisatie, blijkt ook uit een onderzoek van Ansell et al. (1981), waarbij kokkels na verzameling uit het veld voor bepaalde tijd konden acclimatiseren aan verhoogde temperaturen. Echter, het effect van acclimatisatie op de $\mathrm{LT}_{50}$ (mediane lethale tijd) was niet significant voor $C$. edule (wel voor $C$. tuberculatum en $C$. glaucum). Als temperaturen meer geleidelijk veranderen (zoals door opwarming van de aarde), dan hebben organismen de tijd om zich aan te passen door productie van heat shock proteins, aanpassen van respiratie snelheid en enzymactiviteit (Gosling, 2004; Helmuth \& Hofmann, 2001; Lannig et al., 2006; Rodland et al., 2009; Tomanek, 2010; Verdelhos et al., 2015). 


\subsection{Directe effecten van hoge temperaturen}

Te hoge temperaturen kunnen directe negatieve effecten hebben op de respiratie van kokkels en hun filtreercapaciteit (Gosling, 2004; Helmuth \& Hofmann, 2001; Rodland et al., 2009), het kan leiden tot gedragsveranderingen, zoals verminderde capaciteit om zich in te graven (Ansell et al., 1981; Helmuth \& Hofmann, 2001; Rodland et al., 2009), en het kan zelfs direct lethaal zijn (Mouthon \& Daufresne, 2006; Parada \& Molares, 2008). Uit een onderzoek naar het effect van temperatuur op kokkels bleek dat de respiratie snelheid significant verminderde (Ansell et al., 1981; Helmuth \& Hofmann, 2001; Rodland et al., 2009) onder verhoogde temperaturen en dat de conditie index (verhouding tussen asvrijdrooggewicht van het vlees en de schelp) afnam (Zhou, In prep).

Kokkels kunnen hun gedrag tot op zekere hoogte aanpassen (ingraven) en zo omgaan met hogere temperaturen. Bij oplopende temperaturen graven ze zich dieper in zodat ze ontsnappen aan de hitte. Ze bewegen weer naar het oppervlakte als er water over het sediment stroomt. Echter, kokkels die tijdens laag water in poeltjes leven, bleken juist naar het oppervlak toe te bewegen tijdens hoge temperaturen (Zhou, In prep). Ze zijn dan gevoeliger voor onder andere predatoren.

\subsection{Indirecte effecten van hoge temperaturen}

Naast directe effecten van hoge temperaturen, kunnen ook indirecte of synergetische effecten optreden. De aanwezigheid van organisch materiaal kan, in combinatie met hoge temperaturen, leiden tot zuurstofloosheid in het water en sediment (Burdon et al., 2014). Een onderzoek naar de zoetwater tweekleppigen Anodonta cygnea en Margaritifera falcata laat zien dat de tijd tussen dat de klep open stond en het sluiten van de klep afnam bij verhoogde temperaturen, wat duidt op een verhoogde zuurstofbehoefte (Wilson \& Elkaim, 1997). Dit is geen directe consequentie van de hogere temperatuur, maar een fysiologische beperking om zuurstof op te nemen en het metabolisme actief te houden. Het zuurstofgehalte heeft een effect op de maximale temperatuurtolerantie van tweekleppigen, wat blijkt uit een studie van Pörtner et al. (2006) waarbij de maximale temperatuurtolerantie van Laternula elliptica met $2,5^{\circ} \mathrm{C}$ steeg als gevolg van verdubbeling van de hoeveelheid zuurstof in het water. Mogelijk is het zuurstofgehalte op de droogvallende platen van de Oosterschelde afgenomen waardoor de temperatuurtolerantie van kokkels verlaagd is. Verschillende typen sediment laten verschillende patronen zien in opwarming (Suykerbuyk et al., 2021) en hoeveelheid zuurstof die vastgehouden wordt (Neira et al., 2015). Voornamelijk op de Oesterdam komt anorganisch materiaal voor in de bodem (zwart stinkend sediment op enkele centimeters diepte) waar geen zuurstof bij kan. Dit zou een effect kunnen hebben op de overleving van kokkels op deze locatie.

Ook parasieten kunnen een bijdrage leveren aan sterfte van kokkels. Uit een onderzoek naar grote kokkelsterfte in de Oosterschelde in 2010 bleek dat de kokkels zwaar geïnfecteerd waren met een aantal soorten trematoden (parasiet die kokkels als tussengastheer gebruikt) (van den Brink et al., 2010). Zowel het aantal geïnfecteerde kokkels was hoog, als het aantal parasieten per kokkel. Het was niet duidelijk of deze parasieten de initiële oorzaak waren van de grote sterfte. Waarschijnlijk hebben ook andere factoren een rol gespeeld, zoals verzwakking tijdens de voorgaande strenge winter.

\subsection{Fysiologische processen bij hoge temperaturen}

Onder suboptimale condities (hoge temperaturen) vindt een shift plaats in de energiehuishouding van een organisme; de energie wordt niet meer gebruikt voor essentiële processen (groeien, eten, reproductie of beweging), maar voor onderhoud (Kordas et al., 2011; Pörtner, 2001). Aanpassing van de energiebalans kan deels door acclimatisatie, maar als temperatuursveranderingen te plotseling zijn en organismen geen tijd hebben om zich aan te passen, zullen stress en verminderde weerstand onvermijdelijk zijn (Lannig et al., 2006). Kokkels die plotseling te maken krijgen met extreme temperaturen tijdens een hittegolf, kunnen hun energie mogelijk alleen nog gebruiken voor onderhoud (Kordas et al., 2011). Als dat te lang aanhoudt en ze dus geen voedsel binnenkrijgen, zal dat leiden tot stress en uiteindelijk tot sterfte (Mouthon \& Daufresne, 2006; Parada \& Molares, 2008).

De mate waarin dieren in het intergetijdengebied worden blootgesteld aan bepaalde temperaturen varieert per seizoen. Uit een studie van Chapple et al. (1998) blijkt dat seizoensgebonden veranderingen 
in thermische tolerantie van Mytilus edulis (gewone mossel) nauw gecorreleerd zijn met de hoeveelheid stresseiwitten. Tijdens extreme hitte zijn stresseiwitten (hsp70) voor veel organismen belangrijk voor overleving, maar ze hebben ook hoge energetische kosten (Hofmann, 1996). Coleman et al. (1995) stellen dat als het produceren van stresseiwitten veel energie kost, natuurlijke selecte ervoor gezorgd zal hebben dat de kosten/baten ratio optimaal is, waardoor de hoeveelheid stresseiwitten afhankelijk zal zijn van de omgeving. Dat blijkt het geval bij Drosophila (fruitvlieg). Bij een normale omgevingstemperatuur heeft Drosophila weinig stresseiwitten, maar deze eiwitten nemen explosief toe onder extreme omstandigheden (Feder et al., 1992). Dat de hoeveelheid stresseiwitten afhankelijk is van de omgevingstemperatuur, wordt ook aangetoond in een studie naar M. trossulus (mossel), waarbij hogere niveaus van stresseiwitten worden gevonden in individuen die in de zomer zijn verzameld dan in de winter (Hofmann \& Somero, 1995). De synthese van stresseiwitten in M. trossulus gebeurt tijdens hoogwater, terwijl het metabolisme tijdens laagwater onderdrukt is waardoor weinig energie beschikbaar is voor de synthese van stresseiwitten tot het weer hoogwater is. Als dit bij kokkels ook het geval is, dan kan dit ertoe leiden dat kokkels op een lagere droogvalduur meer tijd hebben om stresseiwitten te produceren waardoor ze in staat zijn beter met de hitte tijdens laagwater om te gaan.

\subsection{Zomersterfte in het buitenland}

In 2019 is een reviewstudie uitgevoerd naar alle potentiële extrinsieke factoren die bijdragen aan massasterfte van tweekleppigen (Soon \& Ransangan, 2019). In deze review wordt massasterfte omschreven als de plotselinge sterfte van minstens $30 \%$ van de populatie (Soletchnik et al., 2007). De potentiele factoren die genoemd worden zijn stormen, hoge concentratie slib, fluctuaties in zoutgehalte en temperatuur, anoxia, voedselbeschikbaarheid, predatie en toxische componenten. Concluderend wordt in dit rapport gesteld dat het moeilijk is om één oorzaak van massasterfte aan te wijzen, maar dat het vaak een combinatie van factoren is. Zo hebben bijvoorbeeld hoge temperaturen in combinatie met de aanwezigheid van organisch materiaal tot massasterfte van juveniele kokkels ( $C$. edule) geleid in Arcachon Bay (Guillou \& Tartu, 1994) en in Galicia (Gonzalez \& Camacho, 1984). Hier was waarschijnlijk de combinatie van hoge temperaturen met anoxia de achterliggende oorzaak (Guillou \& Tartu, 1994). Een andere reviewstudie van Burdon et al. (2014) heeft gekeken naar de oorzaken van massale kokkelsterfte. Er is gekeken naar acht mogelijke oorzaken (o.a. temperatuur, parasieten, voedselbeschikbaarheid), waarbij ook hier opgemerkt wordt dat eigenlijk nooit één oorzaak ten grondslag ligt aan massale sterfte. Het is bekend dat hoge temperaturen sterfte kunnen veroorzaken onder tweekleppigen. Maar aangezien de temperatuurranges van tweekleppige soorten vrij gelijkaardig zijn, zou je verwachten dat een hittegolf effect heeft op meerdere soorten. Daarom is het onwaarschijnlijk dat enkel temperatuur een invloed heeft.

In de late zomer van 2004 werd een grote kokkelsterfte waargenomen in de Duitse Waddenzee. Thieltges (2006) wees parasieten zoals de trematode Gymnophallus choledochus aan als belangrijke factor in de grootschalige sterfte. De trematoden die werden aangetroffen waren volledig ontwikkeld en het is dus te verwachten dat deze al langere tijd (maanden) in de kokkels aanwezig zijn geweest. De kokkels zullen dus niet pas geïnfecteerd zijn terwijl zij aan het oppervlak lagen. Hij stelt echter dat de aanwezigheid van parasieten niet de enige oorzaak zal zijn geweest, aangezien niet alle dode kokkels waren geïnfecteerd met G. choledochus. Mogelijk hebben bacteriële infecties, omgevingsfactoren of hoge kokkeldichtheden (verdringing) een rol gespeeld (Blanchet et al., 2003; Desclaux et al., 2002; Mouritsen, 1997; Richardson et al., 1993), maar die zijn niet onderzocht in het onderzoek van Thieltges. In Nieuw-Zeeland werd na een extreem warme zomer in 2009 massale kokkelsterfte (Austrovenus stutchburyi) waargenomen (Tricklebank et al., 2020). Extreem hoge temperaturen zouden geleid hebben tot verzwakking van de kokkels met een grotere kans op besmetting door ziekteverwekkers tot gevolg. De kokkels werden geïnfecteerd door mycobacteriën en parasieten die de kieuwen infecteerden. Uit bovenstaande informatie blijkt dat het erg lastig is om de hoofdoorzaak van grootschalige sterfte te identificeren omdat er veel complexe interacties zijn tussen schelpdieren en hun omgeving. De doodsoorzaak ligt vaak niet bij één factor maar is een combinatie van factoren. Extrinsieke factoren kunnen schelpdieren zwakker maken, waardoor ze vatbaarder zijn voor bijvoorbeeld hoge temperaturen of parasieten. 


\section{Discussie}

\section{$5.1 \quad$ Sterfte}

Met een sterfte van $95 \%$ onder de 1 -jarige kokkels en $81 \%$ onder de 2 -jarige kokkels, lag de sterfte onder 1- en 2-jarigen hoger dan voor meerjarige kokkels (sterfte van 68\%). De laagst waargenomen sterfte was gemeten onder de meerjarige kokkels op de Slikken van den Dortsman, namelijk $41 \%$. De hoogste sterfte was gevonden onder de 1-jarige kokkels op de Oesterdam, namelijk $96 \%$. Dit is in tegenstelling met wat je zou verwachten op basis van paaigedrag van kokkels (Troost \& Van Asch, 2018). Kokkels paaien meestal pas vanaf hun tweede zomer (Cardoso et al., 2009). De 2-jarige en meerjarige kokkels hebben waarschijnlijk aan het begin van de zomer gepaaid. Ze zijn daarbij een groot deel van hun lichaamsmassa (en dus energie) kwijtgeraakt. Om die reden zou te verwachten zijn dat oudere kokkels met een slechtere conditie de hete zomer in zijn gegaan dan de 1-jarige kokkels, resulterend in hogere sterfte. Op basis van huidig onderzoek blijkt dat echter niet het geval. Het zou kunnen zijn dat de 1-jarige kokkels wel al gepaaid hadden waardoor ook deze leeftijdsklasse een slechtere conditie had alvorens de warme zomer begon. Daarnaast zou de oorzaak kunnen liggen bij het lage aantal meerjarige kokkels dat is aangetroffen in zowel het voor- als najaar. De lage aantallen maken het moeilijk om op basis daarvan de conclusie te trekken dat sterfte lager was onder meerjarige kokkels. Dat sterfte onder 2-jarige kokkels lager bleek dan voor 1-jarige kokkels zou mogelijk eveneens toe te schrijven zijn aan andere factoren dan daadwerkelijk lagere sterfte. Mogelijk zijn stressringen aangezien voor jaarringen waardoor 1-jarige kokkels zijn geclassificeerd als 2-jarige kokkels en daardoor sterfte onder 2-jarigen is overschat en onder 1 -jarigen is onderschat.

De sterfte onder alle leeftijdsklassen samen varieerde van $62 \%$ op de Roggenplaat, tot $94 \%$ op de Oesterdam. De totale sterfte op de Slikken van den Dortsman volgde kort op de Roggenplaat, namelijk $92 \%$. De gemiddeld gemeten sterfte in de Oosterschelde over alle locaties was $88 \%$.

Van 1992 tot 2002 hebben Kamermans et al. (2003) onderzocht wat de sterfte van kokkels was op een aantal vaste plaatsen (vakken) in de Oosterschelde. De 16 vakken van 40 bij $40 \mathrm{~m}$ in de Oosterschelde zijn door de jaren heen zoveel mogelijk hetzelfde gehouden. Daarnaast zijn in 1996 en 2000 t/m 2002 in de maanden september tot december najaarinventarisaties na de visserij uitgevoerd. In 1996 is gebruik gemaakt van een zuigkor vanaf een kokkelvaartuig en in de jaren $2000 \mathrm{t} / \mathrm{m} 2002$ is bemonsterd met een kokkelschepje. Een uitgebreide beschrijving van de methodiek is terug te vinden in de rapportage van Kamermans et al. (2003). Hieruit bleek een gemiddelde zomersterfte van $28 \%$, en een gemiddelde sterfte gemeten over een jaar van ca. 60\%. (Figuur 8). De herbemonstering na de massale sterfte in de zomer van 2018 (Troost \& Van Asch, 2018) laat een veel hoger sterftepercentage zien en

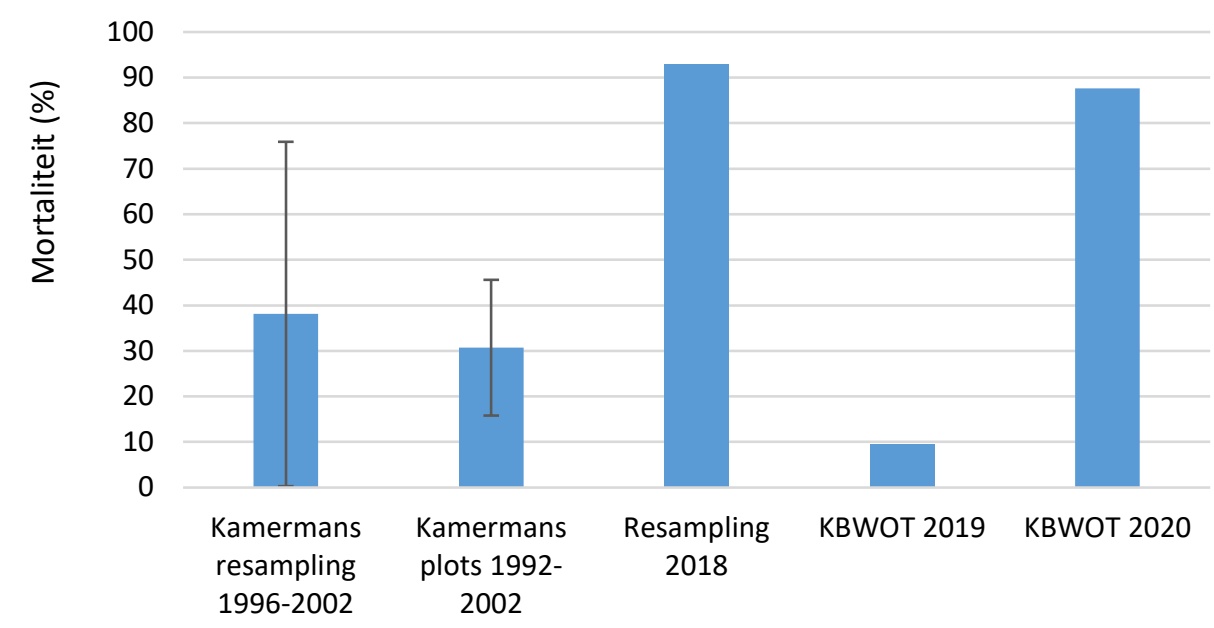

Figuur 8. Gemiddelde kokkelsterfte gedurende de zomermaanden in de Oosterschelde op basis van verschillende onderzoeken. 
sluit daarmee beter aan op de resultaten uit voorliggend onderzoek. De waargenomen zomersterfte in 2020 van $88 \%$ is daarmee onder alle leeftijdsklassen aan de hoge kant te noemen.

\subsection{Koppeling hittestress}

Aangezien onderzoek naar sterfte van kokkels en opbouw van temperatuur in de bodem van intergetijdenplaten zeer complementair is, is besloten om dit onderzoek te koppelen aan het Hittestress project. De resultaten uit beide projecten zijn beschreven in Suykerbuyk et al., (2021). In deze paragraaf wordt de koppeling met het hittestress project beknopt weergegeven, waarbij verwezen wordt naar relevante literatuur uit hoofdstuk 4.

Het achterhalen van oorzaken van de sterfte kunnen mogelijk gezocht worden in oplopende temperaturen in de bodem. Van 5 t/m 17 augustus 2020 is er een landelijke hittegolf geweest met laagwater periodes overdag. Dat heeft ertoe geleid dat maximumtemperaturen in de bodem hoog opliepen. Te hoge temperaturen kunnen directe (vermindering respiratie en filterend vermogen, gedragsverandering, sterfte) en indirecte (verminderde temperatuurtolerantie bij lager zuurstofgehalte) negatieve effecten hebben op kokkels (zie hoofdstuk 4). Aangezien enkel in mei en september kokkelbemonsteringen zijn uitgevoerd, kan enkel op basis van persoonlijke observaties iets gezegd worden over de timing van de sterfte gedurende de zomer. Op 12 augustus, tijdens de hittegolf, kwam de eerste melding binnen van extreme kokkelsterfte in de Oosterschelde.

Op basis van de gegevens van de temperatuursensoren van Suykerbuyk et al. (2021) blijkt dat de temperaturen in de bodem binnen een dag op kunnen lopen van ca. $19^{\circ} \mathrm{C}$ tot $35^{\circ} \mathrm{C}$ en enkele uren op de hoogste temperatuur blijven steken. Mogelijk leidt dit temperatuurverschil tot verandering van fysiologische processen in kokkels en uiteindelijk tot sterfte. Onder condities met hoge temperaturen wordt de energie namelijk niet meer gebruikt voor essentiële processen (groeien, eten, reproductie of beweging), maar voor onderhoud (zie hoofdstuk 4). Het is belangrijk om te weten bij welke temperatuur en voor hoeveel uur irreversibele effecten optreden en dus leiden tot sterfte. In het onderzoek door Verdelhos et al. (2015) werden de kokkels aan een bepaalde constante temperatuur blootgesteld, terwijl in de natuur de temperatuur fluctueert. Het is niet duidelijk wat het effect is van tussenposes waarin de temperatuur weer binnen de optimale range van kokkels valt en hoeveel tijd kokkels nodig hebben om te herstellen van suboptimale condities. Hier kunnen experimenten in het lab meer duiding aan geven. Daarnaast kwamen de kokkels in het onderzoek van Verdelhos et al. uit Portugal, waardoor deze mogelijk een andere optimumtemperatuur hebben dan Nederlandse kokkels die aan koudere watertemperaturen gewend zijn. Om te ontsnappen aan hoge temperaturen in het sediment, kunnen kokkels zich dieper ingraven. Uit de temperatuurmetingen blijkt echter dat ook op grotere diepte $(10 \mathrm{~cm})$ temperaturen worden bereikt van $25-30{ }^{\circ} \mathrm{C}$. Tijdens laagwater kunnen kokkels dus niet ontsnappen aan de hitte door zich dieper in te graven, aangezien daar de temperaturen net zo hoog oplopen als op $3 \mathrm{~cm}$ diepte. Wanneer temperaturen voor langere tijd kritische waarden aanhouden, kan dit leiden tot fysiologische stress en uiteindelijk tot sterfte.

Als gekeken wordt naar de koppeling tussen de waargenomen sterfte en gemeten temperatuur, lijkt de beste positieve correlatie te bestaan tussen sterfte van 2-jarige kokkels in de gehele Oosterschelde en het aantal aaneengesloten dagen met minstens 3 uur een temperatuur van boven de $25^{\circ} \mathrm{C}$ (Figuur 9). Echter, wanneer niet naar de Oosterschelde als geheel wordt gekeken maar naar de locaties apart van elkaar, is te zien dat de correlatie voornamelijk wordt bepaald door één punt op de Roggenplaat (sterfte op 36\% droogvalduur). Wanneer dit punt linksonder in de grafiek niet wordt meegenomen in de analyse, blijft er weinig tot geen correlatie over tussen sterfte en het aantal aaneengesloten dagen met minstens 3 uur $>25^{\circ} \mathrm{C}$. 


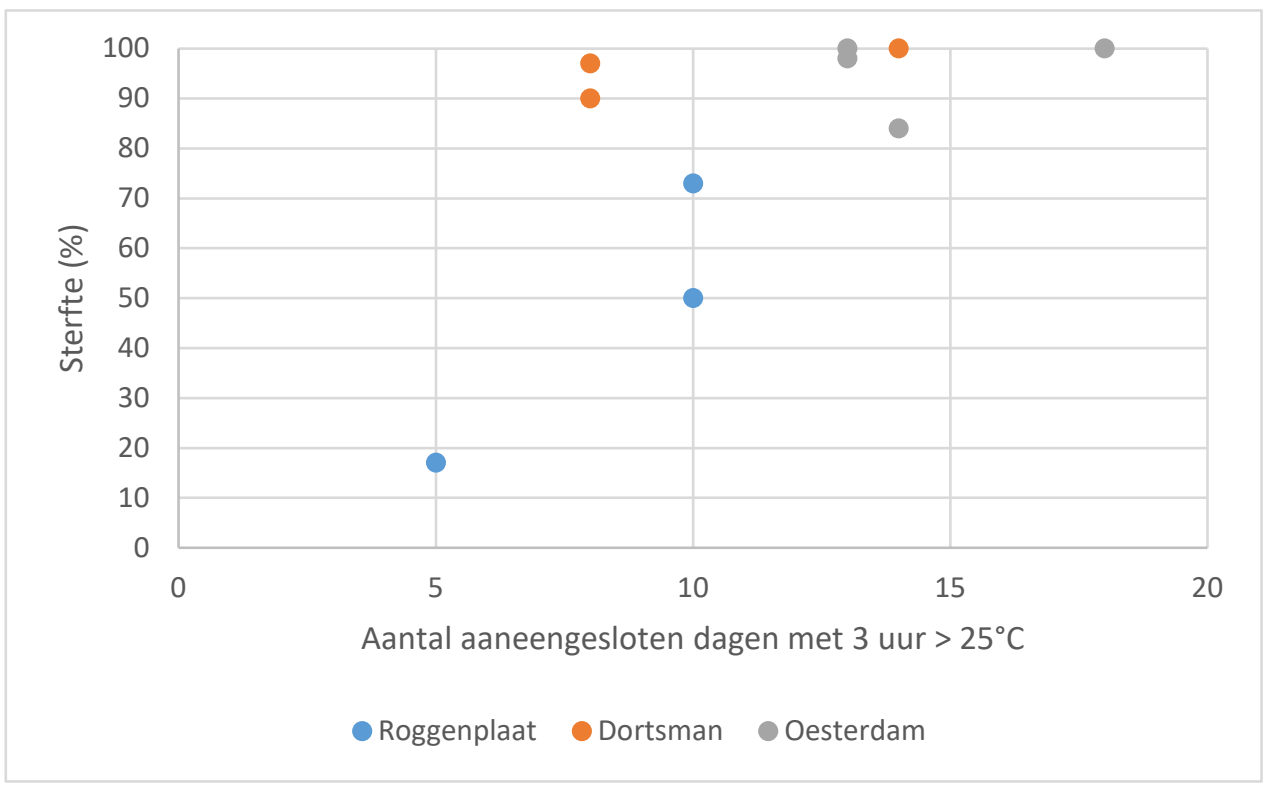

Figuur 9. Sterfte (\%) onder 2-jarige kokkels in de Oosterschelde in 2020 uitgezet tegen het aantal aaneengesloten dagen met minstens 3 uur een temperatuur boven de $25^{\circ} \mathrm{C}$.

Toch zie je wel consequent een positieve correlatie tussen sterfte en temperatuur (Tabel 4). De correlatie is voor alle locaties onder alle temperatuursvariabelen positief of 0 . Dat duidt erop dat er een positief verband is tussen temperatuur en sterfte; hoe hoger de temperatuur, hoe hoger de sterfte. Echter, omdat slechts 3 of 4 waarden per locatie zijn meegenomen in de analyse (sterfte per droogvalduur), is een correlatie niet statistisch vast te stellen. Daarvoor zijn meer waarden nodig die meegenomen kunnen worden in de analyse.

Tabel 4. Correlatie tussen sterfte (1-, 2 - en meerjarige kokkels) en temperatuur. $\mathrm{R}^{2}$ is de determinatiecoëfficiënt en neemt een waarde aan tussen 0 en 1 . Hoe dichter dit getal bij de 1 zit, hoe beter de correlatie is tussen de variabelen. ' + ' geeft aan een positieve correlatie, '-' een negatieve correlatie en '+/-' geen correlatie.

\begin{tabular}{|c|c|c|c|c|c|c|c|c|c|}
\hline & & \multicolumn{2}{|c|}{ Roggenplaat } & \multicolumn{2}{|c|}{$\begin{array}{l}\text { Slikken van } \\
\text { den Dortsman }\end{array}$} & \multicolumn{2}{|c|}{ Oesterdam } & \multicolumn{2}{|c|}{ Totaal } \\
\hline & & $\mathbf{R}^{2}$ & $+/-$ & $\mathbf{R}^{2}$ & $+/-$ & $\mathbf{R}^{2}$ & $+1-$ & $\mathbf{R}^{2}$ & $+1-$ \\
\hline \multirow{2}{*}{ Totaal aantal uren boven } & $25^{\circ} \mathrm{C}$ & 0,93 & + & 0,27 & + & 0,75 & + & 0,22 & + \\
\hline & $30^{\circ} \mathrm{C}$ & 0,97 & + & 0,02 & + & 0,57 & + & 0,09 & + \\
\hline \multirow{2}{*}{$\begin{array}{l}\text { Aantal aaneengesloten dagen } \\
\text { met }>12 \text { uur boven }\end{array}$} & $25^{\circ} \mathrm{C}$ & 0 & $+/-$ & 0,01 & + & 0,02 & + & 0,13 & + \\
\hline & $30^{\circ} \mathrm{C}$ & 0 & $+1-$ & 0 & $+1-$ & 0 & $+/-$ & 0 & $+/-$ \\
\hline \multirow{2}{*}{$\begin{array}{l}\text { Aantal aaneengesloten dagen } \\
\text { met }>6 \text { uur boven }\end{array}$} & $25^{\circ} \mathrm{C}$ & 0,70 & + & 0,32 & + & 0 & $+/-$ & 0,32 & + \\
\hline & $30^{\circ} \mathrm{C}$ & 0 & $+1-$ & 0 & $+1-$ & 0,45 & + & 0,02 & + \\
\hline \multirow{2}{*}{$\begin{array}{l}\text { Aantal aaneengesloten dagen } \\
\text { met }>3 \text { uur boven }\end{array}$} & $25^{\circ} \mathrm{C}$ & 0,57 & + & 0,82 & + & 0,27 & + & 0,40 & + \\
\hline & $30^{\circ} \mathrm{C}$ & 0,80 & + & 0,68 & + & 0,22 & + & 0,16 & + \\
\hline
\end{tabular}


De optimale temperatuurrange voor kokkels is $20-23^{\circ} \mathrm{C}$ (Verdelhos et al., 2015). Tijdens de hittegolf in augustus zijn temperaturen gemeten die hier ver boven kwamen. Uit de resultaten van het onderzoek van Verdelhos et al. (2015) blijkt dat fysiologische processen in kokkels aangetast worden bij temperaturen boven de $23^{\circ} \mathrm{C}$ wat uiteindelijk kan leiden tot sterfte (zie hoofdstuk 4). Het is echter niet bekend in hoeverre kokkels in staat zijn te herstellen na periodes met hogere temperaturen dan hun optimum. Mogelijk is sterfte afhankelijk van de tijd dat ze blootgesteld worden aan hoge temperaturen in combinatie met de tijd die ze krijgen om te herstellen. Een temperatuur van minder dan $23^{\circ} \mathrm{C}$ valt binnen de optimumrange voor kokkels wat ze de mogelijkheid geeft om te herstellen (indien geen onomkeerbare fysiologische processen zijn opgetreden). Uit de resultaten van voorliggend onderzoek blijkt dat sterfte op de Roggenplaat (62\%) een stuk lager ligt dan sterfte op de Oesterdam (94\%) en Dortsman (92\%). Wanneer gekeken wordt naar het aantal uren dat de temperatuur onder de $23^{\circ} \mathrm{C}$ kwam gedurende de hittegolf ( $15 \mathrm{t} / \mathrm{m} 17$ augustus), is te zien dat dit aantal uur veel hoger ligt op de Roggenplaat dan op de andere locaties (gemiddeld 202 uur voor alle droogvalduren t.o.v. 134 uur voor de Dortsman en 83 uur voor de Oesterdam) en dat dit correleert met sterfte (Figuur 10).

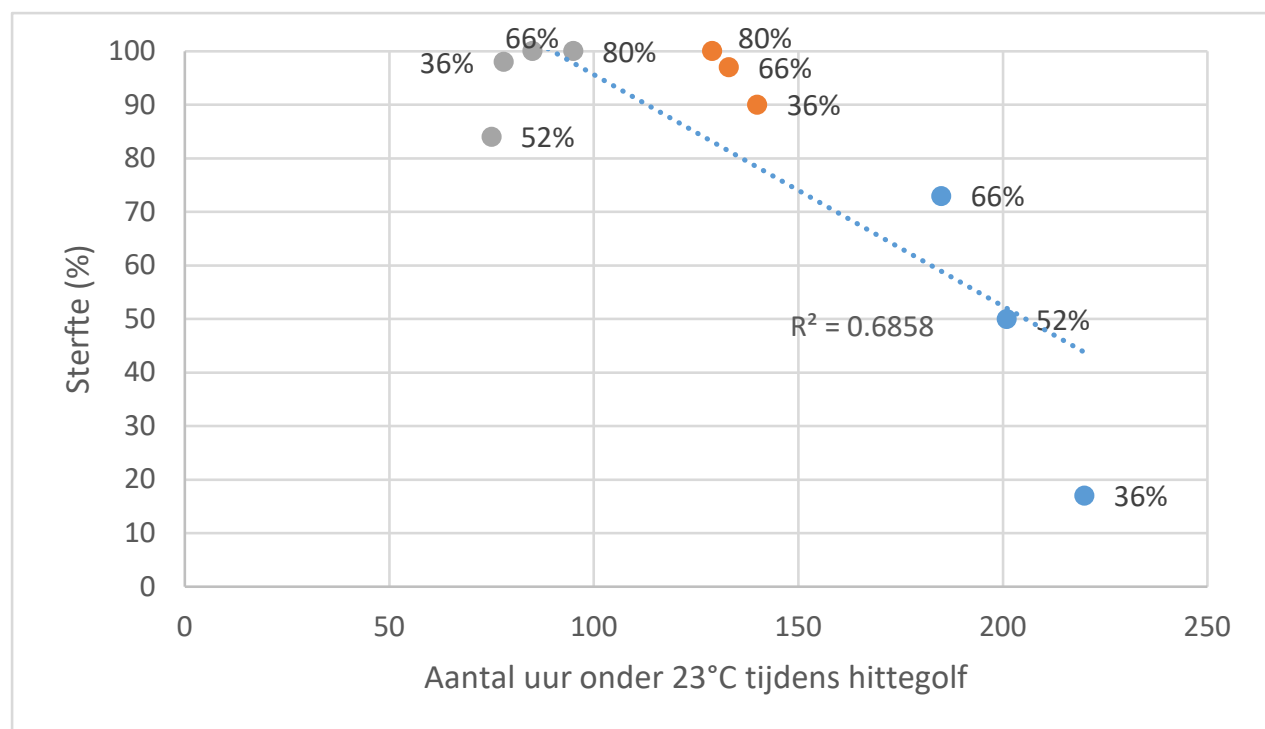

Figuur 10. Sterfte (\%) onder 2-jarige kokkels in de Oosterschelde in 2020 uitgezet tegen het aantal uren onder de $23^{\circ} \mathrm{C}$. Blauwe bolletjes: Roggenplaat; oranje bolletjes: Dortsman; grijze bolletjes: Oesterdam. Droogvalduur is weergegeven als percentage naast ieder bolletje.

Sterfte lijkt af te nemen naarmate het aantal uur onder de $23^{\circ} \mathrm{C}$ tijdens de hittegolf toeneemt. Ook het effect van droogvalduur is hier duidelijk zichtbaar; de laagste droogvalduur (36\%) heeft de meeste uren onder de $23^{\circ} \mathrm{C}$, namelijk 220 . Hoe hoger de droogvalduur, hoe lager het aantal uren onder de $23^{\circ} \mathrm{C}$ en hoe hoger de sterfte. Een verklaring voor de lagere sterfte op de Roggenplaat zou kunnen zijn dat de kokkels gedurende de nacht iets meer tijd gehad hebben om te herstellen van de hoge temperaturen gedurende de dag. Ook op een diepte van $5 \mathrm{~cm}$ en $10 \mathrm{~cm}$ koelt de bodem enkele graden meer af dan op de Oesterdam en Dortsman. De sterfte op de Oesterdam en Dortsman zijn voor alle droogvalduren zodanig hoog, dat binnen deze twee locaties geen trends meer zichtbaar zijn. Mogelijk speelt ook sedimenttype een rol bij de opwarming van de bodem. Oesterdam is slikkiger dan de andere locaties. Slibrijke sedimenten warmen minder snel en hoog op maar koelen ook minder snel af dan zandige sedimenten (Suykerbuyk et al., 2021 en referenties daarin). Bij zandige sedimenten kan water dieper de bodem binnendringen waardoor temperatuureffecten groter zijn. Op de Oesterdam zat op sommige plekken al op enkele centimeters diepte een zwarte zuurstofloze laag. Mogelijk proberen de kokkels aan de hitte te ontsnappen door zich verder in te graven, maar komen dan terecht in een zuurstofloze laag. 


\subsection{Methodiek}

De locaties in de Oosterschelde zijn geselecteerd op onder andere hoge aanwezigheid van kokkels tijdens de bemonstering van 2019.

Het aantal meerjarige kokkels (ouder dan twee jaar) dat is aangetroffen in zowel het voor- als najaar was op vrijwel iedere locatie beperkt. Dit, als gevolg van de zeer hoge sterfte in de zomer van 2018 (Troost \& Van Asch, 2018). Daarbij trad ook een omvangrijke broedval op, wat verklaart waarom de meeste kokkels in de zomer van 2020 twee jaar oud waren. Op de Oesterdam zijn in het voorjaar 16 meerjarige kokkels aangetroffen en op de Slikken van den Dortsman 17. Voor de Roggenplaat waren dat er 40 in het voorjaar. Dit zijn relatief kleine aantallen en geven mogelijk een minder betrouwbaar beeld. Toch is het aantal meerjarige kokkels op de drie locaties met $40 \%$ tot $78 \%$ afgenomen, wat erop duidt dat er wel degelijk hoge sterfte is opgetreden.

In het lab bleek het voor sommige kokkels moeilijk om de leeftijd te bepalen door de aanwezigheid van zogenaamde 'stress-ringen', welke zijn ontstaan doordat de kokkels gedurende een periode in de zomer als gevolg van stress niet gegroeid zijn. Deze ringen lijken veel op de jaarringen die ontstaan doordat kokkels in de winter niet groeien, en zijn daar moeilijk van te onderscheiden. Derhalve zou het aantal jaarringen overschat kunnen zijn waardoor kokkels als ouder zijn bestempeld. Hetzelfde zou andersom kunnen zijn gebeurd; jaarringen zijn aangezien voor stressringen en kokkels zijn juist jonger ingeschat dan ze in werkelijkheid waren. Om dit zoveel mogelijk te voorkomen, zijn de kokkels bij twijfel door een tweede of zelfs derde expert gecontroleerd op leeftijd.

De droogvalduur is bepaald op basis van dieptekaarten van 2016. De droogvalduur is een gemiddelde over een heel jaar en zou daarom voor de gemeten periode enigszins kunnen afwijken. De locaties van de kokkelvakken zijn geselecteerd op deze dieptekaart en zouden dus kunnen afwijken van de werkelijke droogvalduur in de gemeten periode.

\subsection{Toekomst}

Zoals ook beschreven in Suykerbuyk et al. (2021), zullen met de huidige klimaatverandering luchttemperaturen stijgen en worden extremere temperaturen en meer hittegolven verwacht. Als gevolg daarvan zal de watertemperatuur ook stijgen en mogelijk ook al eerder in de zomer zijn afkoelende werking verliezen. Daardoor zouden kokkels langer blootgesteld zijn aan voor hen suboptimale temperaturen, waarbij ze verminderd actief zijn en wat mogelijk hun fitness vermindert. Dit effect zal dan het grootst worden geacht in het oostelijke deel van de Oosterschelde, waar het water langer verblijft, eerder en hoger opwarmt en meer slibrijke sedimenten te vinden zijn. Een kanttekening: uit historische analyse blijkt dat hoge zomertemperaturen minder negatief effect hebben op het kokkelbestand dan strenge winters (Beukema \& Dekker, 2020). Opwarming en daarmee het uitblijven van extreme winters zou dan netto juist positief uit kunnen pakken voor het kokkelbestand. Met de kennis op dit moment blijft het speculeren hoe de kokkelpopulatie zich anders zal gaan ontwikkelen als gevolg van klimaatverandering. We noemen hieronder mogelijke scenario's maar benadrukken dat we op dit moment geen voorspellingen kunnen doen.

Langjarig onderzoek heeft uitgewezen dat zomersterfte onder kokkels gemiddeld $28 \%$ is, met grote verschillen tussen jaren (Kamermans et al., 2003; Figuur 8). De sterftes die zijn bepaald middels een herbemonstering van 2018 (Troost \& Van Asch, 2018) en in deze studie laten zien dat het sterftepercentage nog beduidend hoger kan liggen met als waarschijnlijke oorzaak periodes met extreme hitte. Normaal gesproken worden broed en juvenielen van mariene invertebraten gevoeliger geacht voor hoge temperaturen (Beukema \& Dekker, 2020). Uit de herbemonstering van 2018 bleek dat in de Waddenzee extreme sterfte was opgetreden onder 2-jarige en meerjarige kokkels maar niet onder 1-jarige kokkels (Troost \& Van Asch, 2018). In de Oosterschelde waren echter ook de 1-jarigen massaal gestorven. Uit de resultaten van voorliggend onderzoek lijkt de sterfte het hoogst voor de 1jarige en het laagst voor de meerjarige kokkels. Toch is dat niet statistisch vast te stellen aangezien het aantal meerjarige kokkels dat is aangetroffen erg laag was door massale sterfte in 2018. Analyse van langjarige data van het kokkelbestand in de Waddenzee wijst ook op een hogere gevoeligheid ten aanzien van extreme temperaturen van adulte kokkels ten opzichte van juveniele (Beukema \& Dekker, 2020). Indien in toekomstige jaren de 2-jarige en meerjarige kokkels gevoeliger zijn voor hitte in de zomer en enkel de 1-jarige blijven leven, dan kan er nog een aanzienlijk bestand over blijven dat in het volgende voorjaar of vroege zomer weer kan paaien voordat er eventueel weer een massale 
zomersterfte plaatsvindt. Omdat paaiende kokkels miljoenen eitjes en zaadcellen uitstoten is er een relatief kleine ouderpopulatie nodig om in één seizoen weer een bestand van betekenis te hebben. Dit geldt ook in het scenario waarin sterfte onder 1 -jarige kokkels even hoog is als onder de meerjarige, maar er toch een kleine restpopulatie achterblijft in gebieden waar de omstandigheden minder extreem zijn geweest, zoals het ondiepe sublitoraal dat meestal is bedekt met water (en waar steltlopers er niet bij kunnen). Dan moeten deze individuen echter niet te zeer verzwakt zijn geraakt, moeten ze niet ook nog een strenge winter te verduren krijgen, en voldoende kwalitatief goed voedsel krijgen om hun gonaden weer op te bouwen tot het volgende paaiseizoen. Klimaatverandering zou kunnen leiden tot een verandering in de gemiddelde omvang van het kokkelbestand, tot een verschuiving in de leeftijdsopbouw, of tot een verschuiving in het verspreidingspatroon naar bijvoorbeeld het ondiepe sublitoraal. Op dit moment kunnen we enkel speculeren over de toekomst van de kokkel populatie op de droogvallende platen van de Oosterschelde onder invloed van het vaker optreden van extreme zomersterftes. Om gefundeerde voorspellingen te kunnen doen is meer onderzoek nodig naar bijvoorbeeld de fysiologische respons van kokkels op veranderingen in leefomstandigheden.

\subsection{Aanbevelingen}

Om trends in kokkelsterfte te kunnen monitoren, is het interessant voorliggend onderzoek in de komende jaren te herhalen op dezelfde locaties. Op die manier kan gemonitord worden hoe het aantal kokkels doorheen de tijd veranderd.

Daarnaast zou de koppeling met hittestress verder uitgewerkt kunnen worden. Er zijn experimenten bekend waarbij kokkels in laboratoriumexperimenten worden blootgesteld aan bepaalde temperaturen. Het is echter van belang om te onderzoeken wat het effect is van fluctuerende temperaturen op kokkels, waarbij enkele uren temperaturen worden bereikt van meer dan $30^{\circ} \mathrm{C}$, maar dat deze vervolgens weer afnemen tot $20^{\circ} \mathrm{C}$. In hoeverre kunnen kokkels herstellen na deze extreme temperaturen? En wat is daarvoor nodig (bijv. voldoende voedsel)? Hoe vaak kunnen dit soort pieken optreden alvorens kokkels het lootje leggen? Wanneer treden onomkeerbare fysiologische processen op? En is deze respons hetzelfde voor kokkels uit warmere oorden die wellicht genetisch al beter bestand zijn tegen hoge temperaturen (kokkels komen voor van de Barentszzee tot Marokko (Tyler-Walters, 2007))? Dit soort vragen zouden onderzocht kunnen worden door kokkels onder gecontroleerde omstandigheden bloot te stellen aan verschillende omgevingstemperaturen. Onderliggend onderzoek leert dat hierbij naast aandacht voor effect van piektemperaturen ook aandacht moet zijn voor de effecten van langdurig verminderde afkoeling van de omgeving op het gedrag, de fitness en eventuele sterfte van kokkels. Dit levert waardevolle informatie op over de tolerantie van kokkels ten aanzien van temperatuur en de mogelijke gevolgen daarvan op de fysiologie, populatie op korte en langere termijn. 


\section{Kwaliteitsborging}

Wageningen Marine Research beschikt over een ISO 9001:2015 gecertificeerd kwaliteitsmanagementsysteem. Dit certificaat is geldig tot 15 december 2021. De organisatie is gecertificeerd sinds 27 februari 2001. De certificering is uitgevoerd door DNV GL. 


\section{Literatuur}

Ansell, A., Barnett, P., Bodoy, A., Massé, H., 1981. Upper temperature tolerances of some European molluscs. Marine Biology 65, 177-183.

Beukema, J.J., Dekker, R., 2020. Winters not too cold, summers not too warm: long-term effects of climate change on the dynamics of a dominant species in the Wadden Sea: the cockle Cerastoderma edule $\mathrm{L}$. Mar. Biol. 167, 8.

Blanchet, H., Raymond, N., de Montaudouin, X., Capdepuy, M., Bachelet, G., 2003. Effects of digenean trematodes and heterotrophic bacteria on mortality and burying capability of the common cockle Cerastoderma edule (L.). Journal of Experimental Marine Biology and Ecology 293, 89-105.

Burdon, D., Callaway, R., Elliott, M., Smith, T., Wither, A., 2014. Mass mortalities in bivalve populations: A review of the edible cockle Cerastoderma edule (L.). Estuarine, Coastal and Shelf Science 150, 271280.

Cardoso, J.F., Witte, J.I., van der Veer, H.W., 2009. Differential reproductive strategies of two bivalves in the Dutch Wadden Sea. Estuarine, Coastal and Shelf Science 84, 37-44.

Chapple, J.P., Smerdon, G.R., Berry, R., Hawkins, A.J., 1998. Seasonal changes in stress-70 protein levels reflect thermal tolerance in the marine bivalve Mytilus edulis L. Journal of Experimental Marine Biology and Ecology 229, 53-68.

Coleman, J.S., 1995. Heat-shock proteins and thermotolerance: linking molecular and ecological perspectives. Trends Ecol Evol 10, 305-306.

Compton, T.J., Rijkenberg, M.J., Drent, J., Piersma, T., 2007. Thermal tolerance ranges and climate variability: a comparison between bivalves from differing climates. Journal of Experimental Marine Biology and Ecology 352, 200-211.

Desclaux, C., De Montaudouin, X., Bachelet, G., 2002. Cockle emergence at the sediment surface:'favourization'mechanism by digenean parasites? Diseases of Aquatic Organisms 52, 137-149.

Feder, J.H., Rossi, J.M., Solomon, J., Solomon, N., Lindquist, S., 1992. The consequences of expressing hsp70 in Drosophila cells at normal temperatures. Genes \& development 6, 1402-1413.

Gonzalez, R., Camacho, A.P., 1984. El berberecho, Cerastoderma edule (L.) de Carril (Ria de Arosa) II: Reclutamiento, crecimiento, mortalidad natural y produccion. Act. IV Simp. Iber. Est. Benth. Mar 2, 223-244.

Gosling, E., 2003. Bivalve molluscs: biology, ecology and culture. John Wiley \& Sons.

Gosling, E., 2004. Bivalve Molluscs: Biology, Ecology and Culture. P443. Oxford, Blackwell Science.

Guillou, J., Tartu, C., 1994. Post-larval and juvenile mortality in a population of the edible cockle Cerastoderma edule (L.) from northern Brittany. Netherlands Journal of Sea Research 33, 103-111.

Helmuth, B.S., Hofmann, G.E., 2001. Microhabitats, thermal heterogeneity, and patterns of physiological stress in the rocky intertidal zone. The Biological Bulletin 201, 374-384.

Hofmann, G., 1996. Protein ubiquitination and stress protein synthesis in Mytilus trossulus occurs during recovery from tidal emersion. Mol. Mar. Biol. Biotech. 5, 175-184.

Hofmann, G., Somero, G., 1995. Evidence for protein damage at environmental temperatures: seasonal changes in levels of ubiquitin conjugates and hsp70 in the intertidal mussel Mytilus trossulus. Journal of Experimental Biology 198, 1509-1518.

Kamermans, P., Kesteloo, J., Baars, D., 2003. Eindverslag Evaluatie Schelpdiervisserij tweede fase. Deelproject $\mathrm{H} 2$ : Evaluatie van de geschatte omvang en ligging van de kokkelbestanden in de Waddenzee, de Oosterschelde en de Westerschelde. RIVO-rapport C054/03.

Kordas, R.L., Harley, C.D., O'Connor, M.I., 2011. Community ecology in a warming world: the influence of temperature on interspecific interactions in marine systems. Journal of Experimental Marine Biology and Ecology 400, 218-226.

Lannig, G., Flores, J.F., Sokolova, I.M., 2006. Temperature-dependent stress response in oysters, Crassostrea virginica: pollution reduces temperature tolerance in oysters. Aquatic Toxicology 79, 278287.

Mouritsen, K.N., 1997. Crawling behaviour in the bivalve Macoma balthica: the parasite-manipulation hypothesis revisited. Oikos, 513-520.

Mouthon, J., Daufresne, M., 2006. Effects of the 2003 heatwave and climatic warming on mollusc communities of the Saône: a large lowland river and of its two main tributaries (France). Global Change Biology 12, 441-449.

Neira, J., Ortiz, M., Morales, L., Acevedo, E., 2015. Oxygen diffusion in soils: understanding the factors and processes needed for modeling. Chilean journal of agricultural research 75, 35-44. 
Parada, J.M., Molares, J., 2008. Natural mortality of the cockle Cerastoderma edule (L.) from the Ria of Arousa (NW Spain) intertidal zone. Revista de biología marina y oceanografía 43, 501-511.

Pörtner, H., 2001. Climate change and temperature-dependent biogeography: oxygen limitation of thermal tolerance in animals. Naturwissenschaften 88, 137-146.

Pörtner, H.O., Peck, L.S., Hirse, T., 2006. Hyperoxia alleviates thermal stress in the Antarctic bivalve, Laternula elliptica: evidence for oxygen limited thermal tolerance. Polar Biology 29, 688-693.

Richardson, C., Ibarrola, I., Ingham, R., 1993. Emergence pattern and spatial distribution of the common cockle Cerastoderma edule. Mar Ecol Prog Ser 99, 71-81.

Rodland, D.L., Schöne, B.R., Baier, S., Zhang, Z., Dreyer, W., Page, N.A., 2009. Changes in gape frequency, siphon activity and thermal response in the freshwater bivalves Anodonta cygnea and Margaritifera falcata. Journal of Molluscan Studies 75, 51-57.

Soletchnik, P., Ropert, M., Mazurié, J., Fleury, P.G., Le Coz, F., 2007. Relationships between oyster mortality patterns and environmental data from monitoring databases along the coasts of France. Aquaculture 271, 384-400.

Soon, T.K., Ransangan, J., 2019. Extrinsic factors and marine bivalve mass mortalities: an overview. Journal of Shellfish Research 38, 223-232.

Suykerbuyk, W., Van den Bogaart, L., Hamer, A., Walles, B., Troost, K., Tangelder, M., 2021. Hittestress op intergetijdenplaten van de Oosterschelde. Wageningen Marine Research.

Thieltges, D.W., 2006. Parasite induced summer mortality in the cockle Cerastoderma edule by the trematode Gymnophallus choledochus. Hydrobiologia 559, 455-461.

Tomanek, L., 2010. Variation in the heat shock response and its implication for predicting the effect of global climate change on species' biogeographical distribution ranges and metabolic costs. Journal of Experimental Biology 213, 971-979.

Tricklebank, K.A., Grace, R.V., Pilditch, C.A., 2020. Decadal population dynamics of an intertidal bivalve (Austrovenus stutchburyi) bed: pre-and post-a mass mortality event. New Zealand Journal of Marine and Freshwater Research, 1-23.

Troost, K., 2019. Kokkelbestand Waddenzee. Wageningen Marine Research.

Troost, K., Van Asch, M., 2018. Herziene schatting van het kokkelbestand in de Waddenzee en Oosterschelde in het najaar van 2018. Stichting Wageningen Research, Centrum voor Visserijonderzoek (CVO).

Tyler-Walters, H., 2007. Cerastoderma edule Common cockle. In Tyler-Walters H. and Hiscock K. (eds) Marine Life Information Network: Biology and Sensitivity Key Information Reviews, [on-line]. Plymouth: Marine Biological Association of the United Kingdom. DOI https://dx.doi.org/10.17031/marlinsp.1384.1.

van Asch, M., van den Ende, D., van der Pool, J., Brummelhuis, E. B. M., van Zweeden, C., van Es, Y., Troost, K., 2019. Het kokkelbestand in de Nederlandse kustwateren in 2019. CVO report; No. 19.009 Wageningen UR - Centrum voor Visserijonderzoek (CVO) en Wageningen Marine Research.

van den Brink, A., Troost, K., Engelsma, M., 2010. Kokkelsterfte in de Oosterschelde juni 2010. IMARES.

Verdelhos, T., Marques, J., Anastácio, P., 2015. Behavioral and mortality responses of the bivalves Scrobicularia plana and Cerastoderma edule to temperature, as indicator of climate change's potential impacts. Ecological Indicators 58, 95-103.

Wilson, J., Elkaim, B., 1997. Seasonal and Geographical Differences in Oxygen Consumption with Temperature ofCerastoderma glaucum (Poiret) and a Comparison withC. edule (L.). Estuarine, Coastal and Shelf Science 45, 571-577.

Zhou, Z., Bouma, T., Ysebaert, T., van IJzerloo, L., van Dam, B., Walles, B., In prep. Thermal stress affects bioturbators' burrowing behavior: a mesocosm experiment on common cockles (Cerastoderma edulde). 


\section{Verantwoording}

Rapport C036/21

Projectnummer: 4311300074

Dit rapport is met grote zorgvuldigheid tot stand gekomen. De wetenschappelijke kwaliteit is intern getoetst door een collega-onderzoeker en het verantwoordelijk lid van het managementteam van Wageningen Marine Research

Akkoord:

Datum:

Akkoord:

Handtekening:

Datum:
Pauline Kamermans

Senior onderzoeker

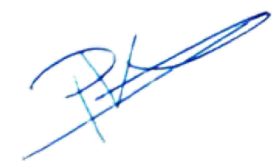

7 april 2021

Drs. J. Asjes

MT lid Integratie

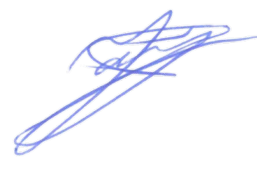

7 april 2021 
Wageningen Marine Research

T: $+31(0) 317480900$

E: marine-research@wur.nl

www.wur.nl/marine-research

Bezoekers adres:

- Ankerpark 271781 AG Den Helder

- Korringaweg 7, 4401 NT Yerseke

- Haringkade 1, 1976 CP IJmuiden
Wageningen Marine Research levert met kennis, onafhankelijk wetenschappelijk onderzoek en advies een wezenlijke bijdrage aan een duurzamer, zorgvuldiger beheer, gebruik en bescherming van de natuurlijke rijkdommen in zee-, kust- en zoetwatergebieden.
Wageningen Marine Research is onderdeel van Wageningen University \& Research. Wageningen University \& Research is het samenwerkingsverband tussen Wageningen University en Stichting Wageningen Research en heeft als missie: 'To explore the potential of nature to improve the quality of life' 